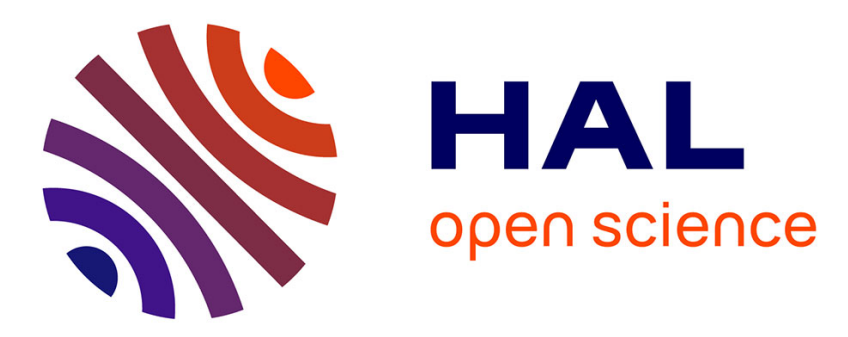

\title{
High biodiversity in Polychelida crustaceans from the Jurassic La Voulte-sur-Rhône Lagerstätte
}

Denis Audo, Günter Schweigert, Jean-Paul Saint Martin, Sylvain Charbonnier

\section{To cite this version:}

Denis Audo, Günter Schweigert, Jean-Paul Saint Martin, Sylvain Charbonnier. High biodiversity in Polychelida crustaceans from the Jurassic La Voulte-sur-Rhône Lagerstätte. Geodiversitas, 2014, 36 (4), pp.489-525. 10.5252/g2014n4a1 . hal-01324863

\section{HAL Id: hal-01324863 https://hal.sorbonne-universite.fr/hal-01324863}

Submitted on 1 Jun 2016

HAL is a multi-disciplinary open access archive for the deposit and dissemination of scientific research documents, whether they are published or not. The documents may come from teaching and research institutions in France or abroad, or from public or private research centers.
L'archive ouverte pluridisciplinaire HAL, est destinée au dépôt et à la diffusion de documents scientifiques de niveau recherche, publiés ou non, émanant des établissements d'enseignement et de recherche français ou étrangers, des laboratoires publics ou privés. 


\title{
High biodiversity in Polychelida crustaceans from the Jurassic La Voulte-sur-Rhône Lagerstätte
}

\author{
Denis AUDO \\ Muséum national d'Histoire naturelle, \\ Département Histoire de la Terre, \\ UMR 7207 CR2P CNRS-MNHN-UPMC, \\ case postale 38, 57 rue Cuvier, F-75231 Paris (France) \\ daudo@edu.mnhn.fr
}

Günter SCHWEIGERT

Staatliches Museum für Naturkunde, Rosenstein 1, 70191 Stuttgart (Germany) guenter.schweigert@smns-bw.de

Jean-Paul SAINT MARTIN

Muséum national d'Histoire naturelle,

Département Histoire de la Terre, UMR 7207 CR2P CNRS-MNHN-UPMC, case postale 38, 57 rue Cuvier, F-75231 Paris (France) jpsmart@mnhn.fr

Sylvain CHARBONNIER Muséum national d'Histoire naturelle,

Département Histoire de la Terre, UMR 7207 CR2P CNRS-MNHN-UPMC, case postale 38, 57 rue Cuvier, F-75231 Paris (France) scharbonnier@mnhn.fr

Audo D., Schweigert G., Saint Martin J.-P. \& Charbonnier S. 2014. - High biodiversity in Polychelida crustaceans from the Jurassic La Voulte-sur-Rhône Lagerstätte. Geodiversitas 36 (4): 489-525. http://dx.doi.org/10.5252/g2014n4a1

\begin{abstract}
The Middle Jurassic La Voulte-sur-Rhône Lagerstätte preserves with remarkable details a highly diversified bathyal palaeocommunity dominated by arthropods. Polychelida Scholtz \& Richter, 1995 are particularly abundant and are currently represented by Eryon ellipticus Van Straelen, 1923, Proeryon giganteus (Van Straelen, 1923), Hellerocaris falloti (Van Straelen, 1923), and Willemoesiocaris ovalis (Van Straelen, 1923). This new investigation reveals the presence of two new genera and three new species in this crustacean community: Voulteryon parvulus n. gen., n. sp., Cycleryon romani n. sp., which is the oldest occurrence of the genus, and Adamanteryon fourneti n. gen., n. sp., an enigmatic polychelidan of
\end{abstract}




\author{
KEY WORDS \\ Eryonidae, \\ Polychelidae, \\ Coleiidae, \\ Callovian, \\ palaeoecology, \\ bathyal, \\ palaeoenvironment, \\ nodule, \\ new genera, \\ new species.
}

MOTS CLÉS

Eryonidae,

Polychelidae,

Coleiidae,

Callovien,

paléoécologie,

bathyal,

paléoenvironnement,

nodule,

genres nouveaux,

espèces nouvelles. uncertain affinities. The genus Proeryon Beurlen, 1928 is also revised to solve problems of homonymy, and as a consequence we here propose the replacement name Proeryon zehentbaueri pro Proeryon giganteus Beurlen, 1930, non Proeryon giganteus (Van Straelen, 1923). These new results place the La Voulte polychelidan lobster community at the first rank in terms of familial and generic diversity (three families, seven genera) and at the second rank in terms of species diversity (seven species) just after the Late Jurassic Eichstätt Lagerstätte (eight species). Thanks to modern techniques, such as X-ray tomography, this study also documents structures never observed before such as thoracic appendages of Proeryon giganteus and Hellerocaris falloti. In the case of Hellerocaris falloti, these new observations suggest it is one of the closest fossil relatives to extant polychelids.

\section{RÉSUMÉ}

Une importante biodiversité des crustacés Polychelida du Lagerstätte jurassique de La Voulte-sur-Rhône.

Le Lagerstätte de La Voulte-sur-Rhône (Jurassique moyen) livre une communauté bathyale très bien conservée et présentant une forte biodiversité dominée par les arthropodes. Les crustacés Polychelida Scholtz \& Richter, 1995 y sont particulièrement abondants et initialement représentés par Eryon ellipticus Van Straelen, 1923, Proeryon giganteus (Van Straelen, 1923), Hellerocaris falloti (Van Straelen, 1923), et Willemoesiocaris ovalis (Van Straelen, 1923). Cette nouvelle étude révèle l'existence de deux nouveaux genres et de trois espèces nouvelles: Voulteryon parvulus n. gen., n. sp., Cycleryon romani n. sp., qui est l'espèce la plus ancienne de ce genre, et Adamanteryon fourneti n. gen., n. sp., un Polychelida énigmatique aux affinités demeurant incertaines. Le genre Proeryon Beurlen, 1928 est également révisé afin de résoudre un problème d'homonymie, ce qui nous conduit à proposer le nom de remplacement Proeryon zehentbaueri pro Proeryon giganteus Beurlen, 1930, non Proeryon giganteus (Van Straelen, 1923). Ces nouveaux résultats montrent que la communauté de Polychelida de La Voulte est la première en terme de diversité familiale (trois familles) et générique (sept genres), et la seconde en terme de diversité spécifique (sept espèces), juste derrière le Jurassique supérieur du Lagerstätte d'Eichstätt (huit espèces). Grâce à la tomographie aux rayons $\mathrm{X}$, des caractères anatomiques encore jamais observés sont décrits, tels que les appendices thoraciques chez Proeryon giganteus et Hellerocaris falloti. Chez Hellerocaris falloti, la mise en évidence de ces appendices semble indiquer qu'il s'agit d'une des espèces fossiles les plus proches des polychelidés actuels.

\section{INTRODUCTION}

Polychelidan lobsters are a peculiar group of decapod crustaceans distinguished by a reduced rostrum, a dorsoventrally flattened body, and five pairs of pereiopods (walking limbs): the first pair is large and clawed; the succeeding pairs are smaller, clawed, except for the last one, which can be clawed in females. The fossil record of polychelidan lobsters is highly discontinuous, as that of most other crustaceans, since they mostly occur in outcrops with exceptional preservation (Lagerstätten). Polychelidans appear in the Triassic (Bronn 1858). 
They are well-documented in the Early Jurassic at Lyme Regis (Hettangian-Sinemurian, five species; Woods 1925), at Osteno (Sinemurian, four species; Pinna 1968, 1969; Teruzzi 1990) and at Holzmaden (Toarcian, four species; Beurlen 1928, 1930, 1944; Hauff \& Hauff 1981). Fossil polychelidans reach the peak of their specific diversity in the Late Jurassic in the "Solnhofen-type" plattenkalks from Germany and France (Kimmeridgian-Tithonian, 11 species; see Audo et al. 2014a).

Since the nineteenth century, the La Voulte-surRhône Lagerstätte (France, Ardèche, Fig. 1) has yielded the most important fauna of polychelidan lobsters from the Middle Jurassic (Charbonnier 2009; Charbonnier et al. 2010).

Studies of polychelidan lobsters from La Voulte were carried out by Van Straelen (1923), who described Eryon ellipticus Van Straelen, 1923 (Fig. 2A), Proeryon giganteus (Van Straelen, 1923) (Fig. 2D), Hellerocaris falloti (Van Straelen, 1923) (Fig. 2J), and Willemoesiocaris ovalis (Van Straelen, 1923) (Fig. 2G). This last species was ascribed by Van Straelen (1925) to Polychelidae, which comprises all extant species of polychelidans. Charbonnier (2009) and Charbonnier et al. (2010) later noticed probable new taxa, but did not describe them.

The focus of the present study is to propose a modern reinvestigation of the La Voulte polychelidans (Figs 2-10). We review Van Straelen's species, describe new species based upon new specimens, and assess the significance of the La Voulte polychelidan lobster diversity.

\section{ABBREVIATIONS}

Institutional abbreviations

FSL Université Claude Bernard Lyon 1 (Villeurbanne);

GGM Gosudarstvenniy Geologicheskiy Musey-State Geological Museum (Moscow);

MHNGr Muséum d'Histoire naturelle de Grenoble; MNHN.F Muséum national d'Histoire naturelle, Collection de paléontologie (Paris);

MSNM Museo Civico di Storia Naturale (Milano);

PIMUZ Paläontologisches Institut und Museum, Universität Zürich (Zurich);

SMNS Staatliches Museum für Naturkunde (Stuttgart);

UJF-ID Université Joseph Fourier, Institut Dolomieu (Grenoble);

UPMC Université Pierre et Marie Curie-Paris 6 (Paris).

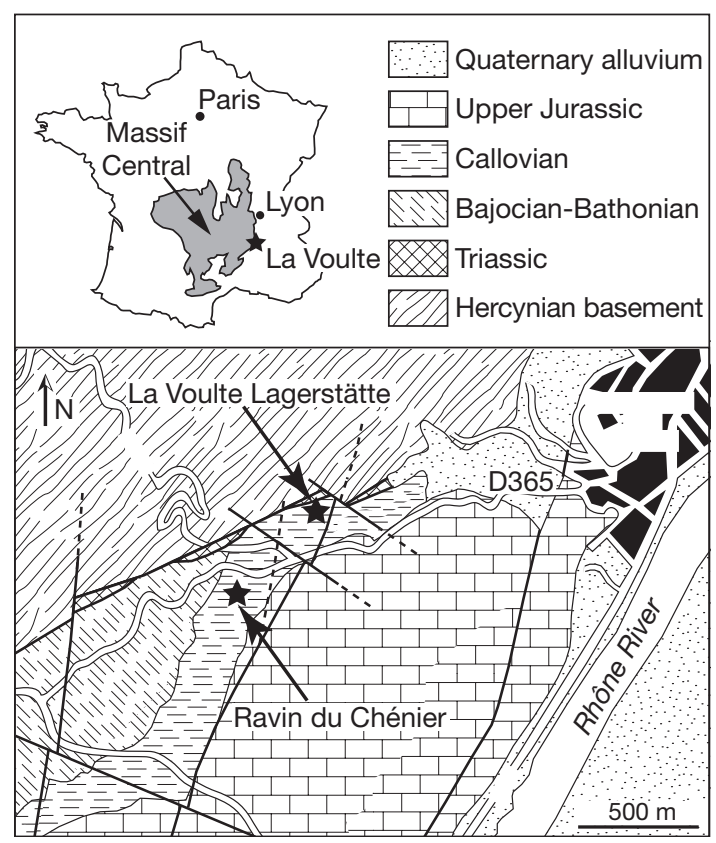

FIG. 1. - Geological map indicating localisation of La Voultesur-Rhône Lagerstätte, modified from Charbonnier et al. (2007a).

\section{Morphological abbreviations \\ P1-P6 pereiopods 1-6; \\ Mx3 third maxilliped; \\ s1-s6 pleonites 1-6.}

\section{LA VOULTE LAGERSTÄTTE}

\section{LA VOULTE BIOTA}

La Voulte-sur-Rhône is a Callovian Lagerstätte celebrated for its exceptionally preserved fauna composed of highly diverse decapod crustaceans (e.g., solenocerids, penaeoids, erymids, stenochirids, eryonoids, coleiids, polychelids, glypheids; Charbonnier et al. 2010, 2013). Other arthropods are thylacocephalans - an enigmatic group with possible crustacean affinities (Secrétan 1985; Vannier et al. 2006) and pycnogonids - a strange group with a scant fossil record (Charbonnier et al. 2007b). By far, the cephalopods are the most famous group from La Voulte. They include possibly the oldest octopus (Wilby 2002; Fischer 2003). There are also annelids, sipuncula worms, and hemicor- 
dates (Alessandrello et al. 2004). Echinoderms are represented by very abundant and fully articulated brittle stars and multi-armed sea stars (Villier et al. 2009). Actinopterygian fishes, coelacanths, sharks, and one marine crocodile have also been reported (Charbonnier 2009). The La Voulte Lagerstätte is unique as it is considered to preserve a deep-sea, probably bathyal palaeoecosystem (Charbonnier 2009). This hypothesis is based on several converging lines of evidence such as the occurrence of vampyromorph squids, pycnogonids, thylacocephalans with hypertrophied eyes, deep-sea siliceous sponges, and stalked crinoids in the nearby outcrop of Ravin du Chénier (Charbonnier et al. 2007a).

\section{GEOLOGICAL SETTING}

The La Voulte Lagerstätte crops out in the Ravin des Mines (Fig. 1), about 1 kilometer west of the village of La Voulte-sur-Rhône (Ardèche Departement, France, c. $150 \mathrm{~km}$ south of Lyon). This outcrop is located on the eastern bank of the Rhône valley, on the southeast margin of the crystalline Hercynian basement of the Massif Central. Structurally, the Lagerstätte belongs to the sediment cover deposited on the Ardèche palaeomargin, a passive margin connecting the submerged Massif Central and the Subalpine Basin, a basin connected to the Tethys Ocean. The geological context of the formation and evolution of the passive margin on which $\mathrm{La}$ Voulte-sur-Rhône Lagerstätte is defined in Elmi $(1967,1990)$ and detailed in Charbonnier et al. (2007a) and Charbonnier (2009).

\section{MATERIAL AND METHODS}

\section{SAMPLING}

The present study is based upon 84 specimens from La Voulte listed before the description of each species. Van Straelen's type material and many historical specimens are housed at the Université Joseph Fourier, Grenoble (ex Institut Dolomieu). Other historical specimens and material collected during field expeditions are housed at the Université Claude Bernard Lyon 1 (Villeurbanne). Finally, fossils collected in La Voulte-sur-Rhône under the supervision of MNHN, Paris and CNRS during the 1983-1986 excavations (for details see Fischer 2003) are housed in the MNHN collections. Finally, a few rare specimens harvested in the middle of the twentieth century or earlier are dispersed in other collections: University of Zurich (Switzerland), Staatliches Museum für Naturkunde, Stuttgart (Germany) and Université Pierre et Marie Curie (Paris 6), France. Most of studied specimens are included within nodules. Other specimens are flattened in marly beds.

\section{IMAGERY}

Specimens were mostly studied using a Wild Heerbrugg TYP 308700 binocular and a camera lucida. Specimens displaying low contrast were imaged either: 1) under cross-polarized light (i.e. light source equipped with a linear polarizing filter and camera lens also equipped with a polarizing filter whose optical axis is perpendicular to that of light source polarizer) to reduce reflexion and glare; or 2) under UV-light for specimens presenting a UV-yellow fluorescence. Some small specimens were imaged on a Hitachi Analytical Table Top Scanning Electron Microscope and a Jeol Neoscope 2 JCM 6000 scanning electron microscope. Photographic close ups of very small specimens were obtained by combining multiple pictures in cross-polarized light by an image stacking program (Zerene stacker, Zerene system Inc.).

\section{X-RAY TOMOGRAPHY}

Additionnaly, specimens UJF-ID.14023 and UJFID. 11551 were imaged by a tomograph v|tome $\mid \mathrm{x} \mathrm{L}$ 240-180 (manufacturer: GE Sensing \& Inspection Technologies - phoenix x|ray) equipped with a microfocus $240 \mathrm{kV} / 320 \mathrm{~W}$ tube, at the MNHN's $\mathrm{X}$-ray tomography imagery platform. Data from $\mathrm{X}$-ray tomograph were saved as series of 16 bits grayscale pictures representing virtual slices of the specimen, grayscale values indicating differences in absorption of $\mathrm{x}$-ray within nodule. These two specimens were then virtually reconstructed as three dimensions models (Figs 6B; 9B) using Mimics software (C) Materialise). Other image stacks were directly visualized on Fiji (Schindelin et al. 2012). 

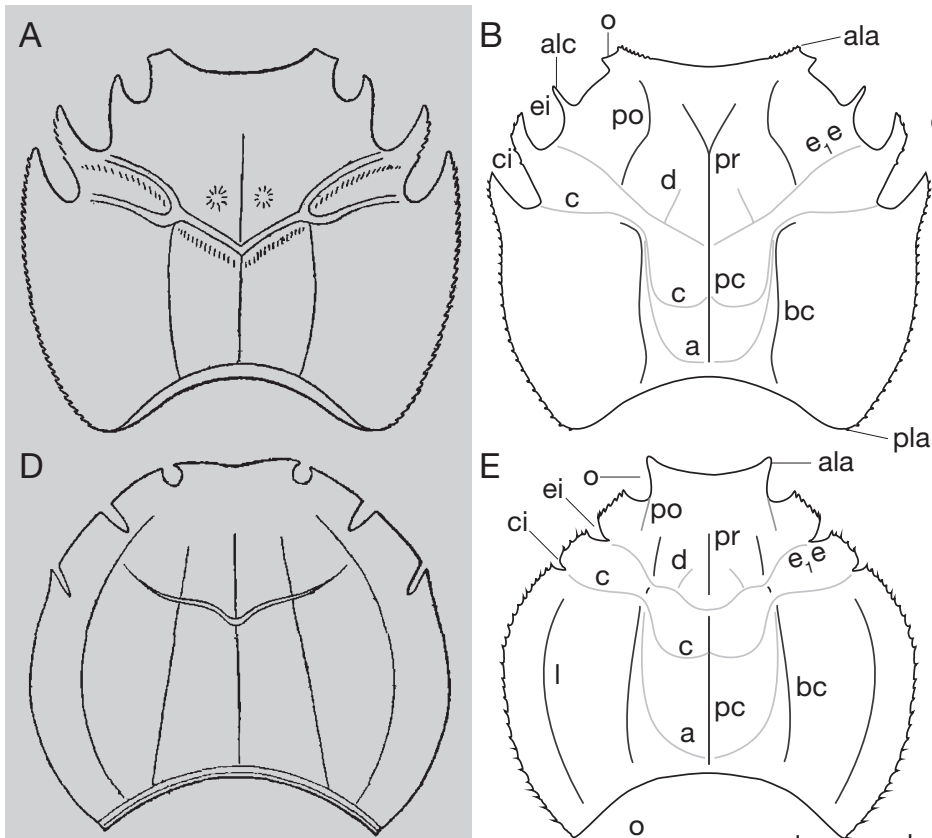

pla
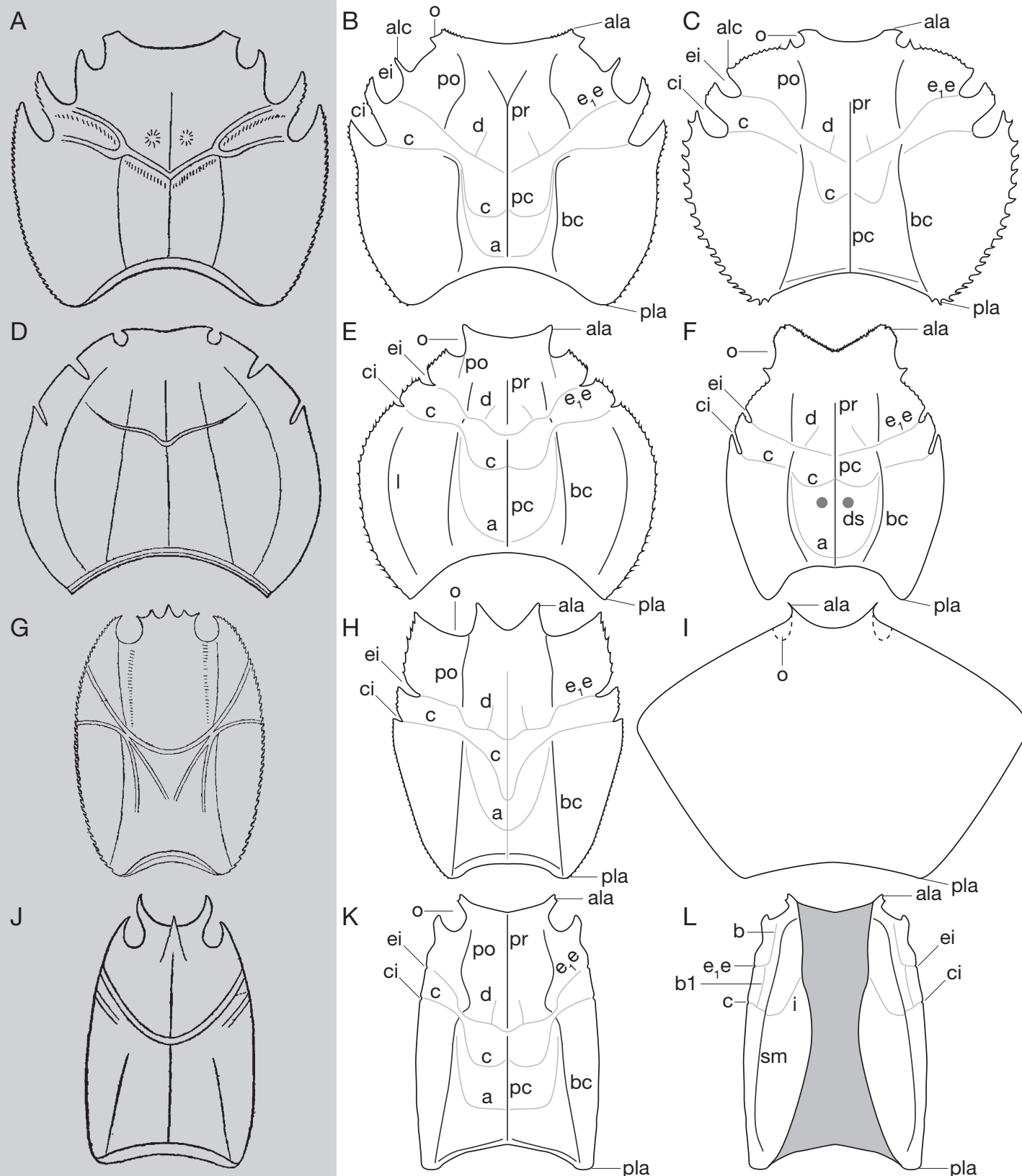

K
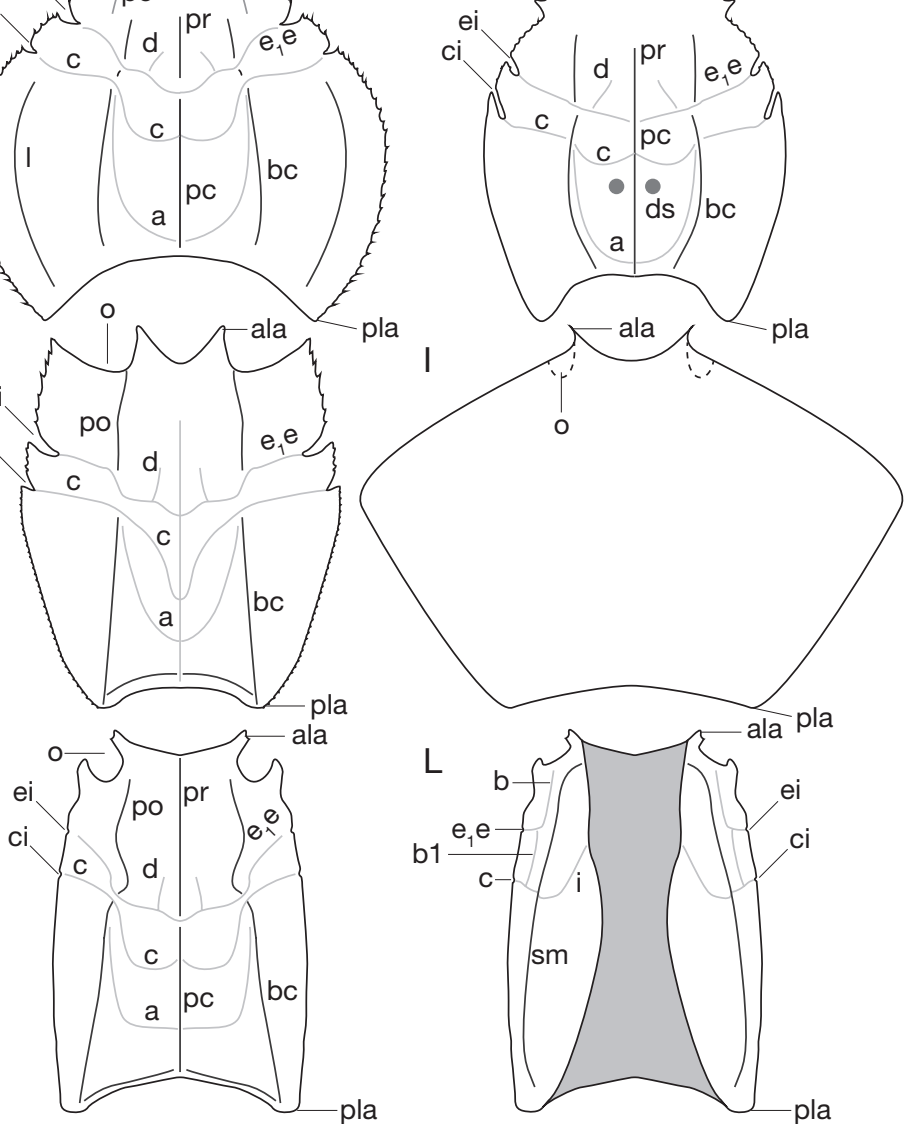

la

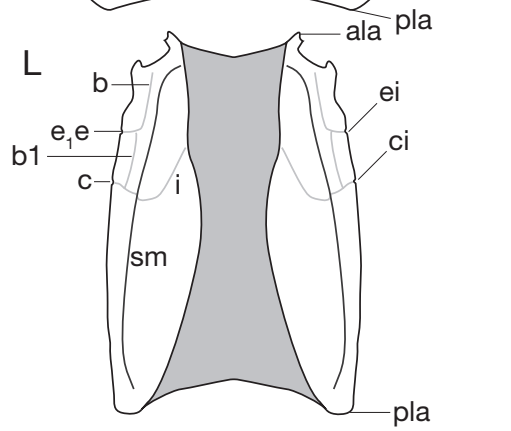

FIG. 2. - Comparison of carapaces of all species described from La Voulte Lagerstätte: A, B, Eryon ellipticus Van Straelen, 1923, former reconstruction by Van Straelen (1923) (A) and current reconstruction (B); C, Cycleryon romani n. sp.; D, E, Proeryon giganteus (Van Straelen, 1923), former (D) and current (E) reconstructions; F, Voulteryon parvulus n. gen., n. sp.; G, H, Willemoesiocaris ovalis (Van Straelen, 1923), former (G) and current (H) reconstructions; I, Adamanteryon fourneti n. gen., n. sp.; J-L, Hellerocaris, former reconstruction of dorsal view $(\mathbf{J})$, current reconstructions of dorsal $(\mathbf{K})$ and ventral $(\mathbf{L})$ views. Abbreviations: a, branchiocardiac groove; ala, anterolateral angle; alc, anterolateral cervical spine; b, antennal groove; b1, hepatic groove; bc, branchial carina; c, postcervical groove; ci, postcervical incision; $\mathbf{d}$, gastro-orbital groove; ds, disc-shaped structure; $\mathbf{e}_{\mathbf{1}} \mathbf{e}$, cervical groove; ei, cervical incision; i, inferior groove; I, lateral carina; o, ocular incision; pc, postcervical carina; po, postorbital carina; pr, postrostral carina; sm, submarginal carina. 


\section{TAPHONOMIC REMARKS}

Observations of the nodule structure from X-ray tomography reveal undocumented features of $\mathrm{La}$ Voulte crustaceans. Crustaceans in nodules are preserved in volume, but more or less vertically compressed. The exoskeletons and soft parts are preserved in minerals absorbing less-X-ray than surrounding matrix, these minerals perhaps corresponds to calcite mentioned by Wilby et al. (1996). The exoskeleton is often coated with a mineral absorbing more X-ray than surrounding matrix, this may correspond to pyrite and/or galena, both observed by Wilby et al. (1996) (see also Fig. 9E representing a specimen coated with pyrite in marly beds). The first pereiopods, the distal part of the pleon, and the telson are often lacking; they do not seem to have been encompassed by the nodule during its formation. Nodules sometimes contain one concentric layer of concretion located between the fossil and surface of nodule. One specimen of Willemoesiocaris ovalis contained within a nodule still preserves parts of its digestive track. However, these sections of digestive track are discontinuous. For these reasons, it seems that the nodules have formed early after the death of the crustacean, after the decay has already begun, but before it led to disarticulation. The nodule growth started near the middle of the specimens, and for some reasons often stopped before encompassing the whole body. Finally, the nodules have been deformed by compaction of surrounding rocks during diagenesis. It is interesting to note that specimens preserved in marly beds seem quite similar in term of fossilization to specimens in nodules, except they are usually more flattened.

\section{SYSTEMATIC PALAEONTOLOGY}

In order to avoid unnecessary discussions of the rank of supra-superfamilial taxa, we here follow Scholtz \& Richter (1995) and do not indicate high taxonomic ranks.

MALACOSTRACA Latreille, 1802

DECAPODA Latreille, 1802

PLEOCYEMATA Burkenroad, 1963
PolyChELIDA Scholtz \& Richter, 1995

Superfamily ERYONOIDEA de Haan, 1841

Family ERYONIDAE de Haan, 1841

Type Genus. — Eryon Desmarest, 1817.

INCLUDED GENERA. - Eryon Desmarest, 1817, Cycleryon Glaessner, 1965, Knebelia Van Straelen, 1923; Rosenfeldia Garassino, Teruzzi \& Dalla Vecchia, 1996, Soleryon Audo, Charbonnier, Schweigert \& Saint Martin, 2014, Tethyseryon Bravi, Garassino, Bartiromo, Audo, Charbonnier, Schweigert, Thévenard \& Longobardi, 2014.

EMENDED DIAGNOSIS. - Widened and rounded carapace not confluent in outline with pleon; uropodal exopod without diaeresis; deep cervical and postcervical incisions (except in Knebelia).

\section{REMARKS}

Eryonidae is probably the best-known family of fossil polychelidan lobsters. Initially, this family used to encompass all polychelidans, but, with the discovery of new species, new families were erected to better describe polychelidan diversity. Eryonidae includes genera characterized by a widened and rounded carapace not confluent in outline with the pleon and an absence of the diaeresis. Moreover, most Eryonidae, except Knebelia are characterized by deep cervical and postcervical incisions. Recently Wrangleryon perates Feldmann, Schweitzer \& Haggart, 2013 was described as an eryonid due to "distinct terga with keeled and subtriangular pleura, subtriangular telson”. First of all, the importance of this discovery should be stressed; it is the single known North American polychelidan (examination of type material of Palaeopentacheles? starri Schweitzer \& Feldmann, 2001 from the early Oligocene of the State of Washington, USA, reveals that it is not a polychelidan but probably a nephropoid lobster, and the structure interpreted as a pectinate claw is the pair of third maxillipeds). Despite the poor state of preservation of the unique specimen of Wrangleryon, it will be noted that pleura are indeed subtriangular, but do not appear to be keeled. Subtriangular pleura, distinct terga and triangular telson are all rather widespread within polychelidan and can be found in the diverse Coleiidae Van Straelen, 1925 and Polychelidae Wood-Mason, 1874. Wran- 
gleryon carapace is not preserved. However, alignment of pereiopods, suggests they probably rested against the lateral margin of carapace. The shape of carapace can therefore be roughly observed: it was with little doubt ovoid and not much wider than the pleon, characters incompatible with an ascription to Eryonidae. Finally, the absence of diaeresis observed on Wrangleryon is truly difficult to assess: exopodal uropods are poorly preserved: the one on the right side of specimen is broken distally; the one on the left side possibly possess a structure reminiscent of a diaeresis but by far too poorly preserved to assess its nature. It must, nevertheless be noted that absence of diaeresis is not unique to eryonids, as it also occurs in polychelids and palaeopentachelids. It seems therefore reasonable to exclude this genus from Eryonidae. However, the question remains open on its place within polychelidans. New, well-preserved specimens may give more clues on the exact affinities of Wrangleryon.

\section{Genus Eryon Desmarest, 1817}

Eryon Desmarest, 1817: 512, 513.

Eryon - Desmarest in Brongniart \& Desmarest 1822: 128, 129. - Lamarck 1838: 376, 377. - Münster 1839: 2, 3. - Pictet 1846: 31, 32. - Oppel 1862: 8-10. - Woodward 1866: 494, 495. - Van Straelen 1925: 113, 114. - Glaessner 1929: 163, 164; 1969: R470. - Charbonnier et al. 2012: 851.

Macrourites-Schlotheim 1820: 37; 1822: 34, 35, pl. 3, fig. 1 (pro parte).

Pagurus - Hebenstreit 1743: 251, pl. 13, fig. 33.

Brachiurus - Knorr 1755: pl. 15, fig. 2.

Locusta Marina, seu Carabus - Bayer 1757: 13, pl. 8, figs 1,2 .

ETYMology. - Unknown: not stated in original work by Desmarest (1817).

Type SPeCies. - Eryon cuvieri Desmarest, 1817 by monotypy (see Charbonnier et al. 2012).

INCLUDED SPECIES. - Eryon cuvieri Desmarest, 1817, E. ellipticus Van Straelen, 1923, E. sublevis Carter, 1886.
EMENDED DIAGNOSIS. - Dorsoventrally flattened carapace, subhexagonal outline in dorsal view; eye carried on elongate peduncule inserted in a tubular protrusion of the anterolateral angle; very wide cervical incision and deep postcervical incision; anterolateral margin separated from cervical incision by a strong and curved anterolateral cervical spine; axial carina on pleonal tergum cutting posterior transverse groove; uropodal exopod without diaeresis.

\section{REMARKS}

Eryon Desmarest, 1817 is the first described genus of polychelidan lobsters. As such, it was used as a catch-all name to accommodate most fossil species of polychelidan lobsters. Although a second polychelidan genus - Coleia Broderip, 1835 - was described, Woodward (1866, 1881, 1911) overlooked the diversity of polychelidan lobsters and ascribed all known species to Eryon. The subdivision of Eryon had to await Knebel (1907) with the groups "Eryonidae latiformes" (= wide eryonoids: Eryon + Cycleryon) and "Eryonidae augustiformes" (= narrow eryonoids: Knebelia, Palaeopentacheles Knebel, 1907, and Palaeopolycheles Knebel, 1907).

In the latest systematic list of fossil decapods, Schweitzer et al. (2010) maintained only five species in Eryon: E. cuvieri, E. ellipticus, E. sublevis, E. neocomiensis Woodward, 1881, and E. perroni Étallon, 1859. However, E. perroni has subsequently been ascribed to another genus (Audo et al. 2014a). Besides, our review of the holotype of E. neocomiensis (BSPG AS-I-994) indicates that it possesses a pyriform carapace, narrow cervical and postcervical incisions, and raised postorbital, branchial, postrostral and postcervical incisions, all differing from the typical Eryonidae habitus.

Eryon ellipticus Van Straelen, 1923

(Figs 2A, B; 3)

Eryon ellipticus Van Straelen, 1923: 90, fig. 7; 1925: 113, 116, fig. 64, pl. 3, fig. 1. — Balss 1924: 175. — Roman 1928: 108, 109, fig. 16, pl. 3, fig. 4. - Glaessner 1929: 165. - Garassino \& Schweigert 2006: 30. - Charbonnier 2009: 158, figs 245, 415; 2010: 102, pl. 2, fig. 6. - Schweitzer et al. 2010: 43. - Charbonnier et al. 2010: 115-117, fig. $4 \mathrm{f}$. 
ETYMology. - Not indicated in original description, probably alluding to the roughly elliptic outline of the carapace.

Type MATERIAL. - Holotype: UJF-ID.11540ab (coll. Gevrey, part [Fig. 3A, B] - and counterpart), by monotypy.

TyPe LOCAlity. - Ravin des Mines, near La Boissine, La Voulte-sur-Rhône Lagerstätte, Ardèche, RhôneAlpes, France.

TYPE AGE. - Early Callovian, Gracilis ammonite Zone.

AdDitional SPECiMENS. - FSL 170752 (coll. Caillet, Fig. 3C, D). - MNHN.F.A00189 (coll. Fischer, Fig. 3G), MNHN.F.A32534 (coll. Charbonnier, Fig. 3E, F). - UJFID.14025 (coll. Gevrey). — UPMC-249.

DiAGNOSIS. - Dorsoventrally flattened carapace with a subhexagonal outline in dorsal view; slightly concave frontal margin, connected seamlessly to the tubular protrusion at anterolateral angle; anterolateral margin separated from cervical incision by a large anterolateral cervical spine; mediolateral margin reduced to a large spine separating cervical and postcervical incisions; spiny posterolateral margin; cervical groove shallow near the cervical incision, faint around branchial carina, deep from the branchial carina to the median line and abruptly ending near median line without cutting it; deep postcervical groove extending from postcervical incision to median line, effaced near branchial carina, and curving forward before cutting median line.

\section{DESCRIPTION}

\section{Carapace outline}

Dorsoventrally flattened carapace with subhexagonal outline in dorsal view; slightly concave frontal margin, connected seamlessly to the tubular protrusion housing eye peduncle at the anterolateral angle; anterior margin of tubular protrusion ornamented by thin spines; lateral margin with cervical and postcervical incisions; shallow ocular incision at the distal extremity of tubular protrusion; slightly concave anterolateral margin, separated from cervical incision by a large and curved anterocervical spine, oblique to longitudinal axis; deep, wide triangular cervical incision; mediolateral margin reduced to a very large spine-like expansion of carapace, shorter than anterolateral margin, ornamented by a few small and forwardly curved spines; deep postcervical incision; straight posterolateral margin, with small spines; subquadrate posterolateral angle, not contiguous to pleon; concave posterior margin.

\section{Carapace carinae and grooves}

Postrostral and postcervical carina not separated by cervical groove; strongly raised postrostral carina, flanked by a row of small tubercles on each side, extending on two thirds of cephalic region before dividing anteriorly in two, oblique, faint carinae; strongly raised postcervical carina flanked by a row of small tubercles on each side; postorbital and branchial carinae merged, forming a long, raised carina, marked by a row of tubercles, extending from near the base of the tubular protrusion, curving inward on cervical region, and outward between cervical and branchial regions, cut by cervical and postcervical grooves, extending backward and slightly outward posteriorly; cervical groove shallow near the cervical incision, faint around branchial carina, deep from the branchial carina to the median line and abruptly ending near median line without cutting it; deep postcervical groove extending from postcervical incision to median line, effaced near branchial carina, and curving forward before reaching median line without cutting it; branchiocardiac groove very faint, extending from postcervical groove, along the branchial carina anteriorly, curving inward posteriorly to reach median line; shallow gastro-orbital groove extending obliquely from cervical groove near branchial carina toward postrostral carina.

\section{Pleon}

Pleon half wide as carapace; $s 1$ tergum shorter than the others; subrectangular s2-s5 terga bearing two transverse grooves converging medially, and an axial carina stretching from behind anterior transverse groove, cutting the posterior one and reaching posterior margin; subtriangular s2-s3 tergopleura (part of terga folded laterally), with a small axial process at the fold separating tergopleura from terga; s4-s5 poorly preserved.

\section{Eyes and cephalic appendages}

Small pear shaped eyes carried on a rather long peduncle and projected from a tubular protrusion; antennula composed of a few proximal oblong podomeres carrying a flagellum of not assessable length, probably rather long (second flagellum not preserved); antenna composed of an antennal pe- 

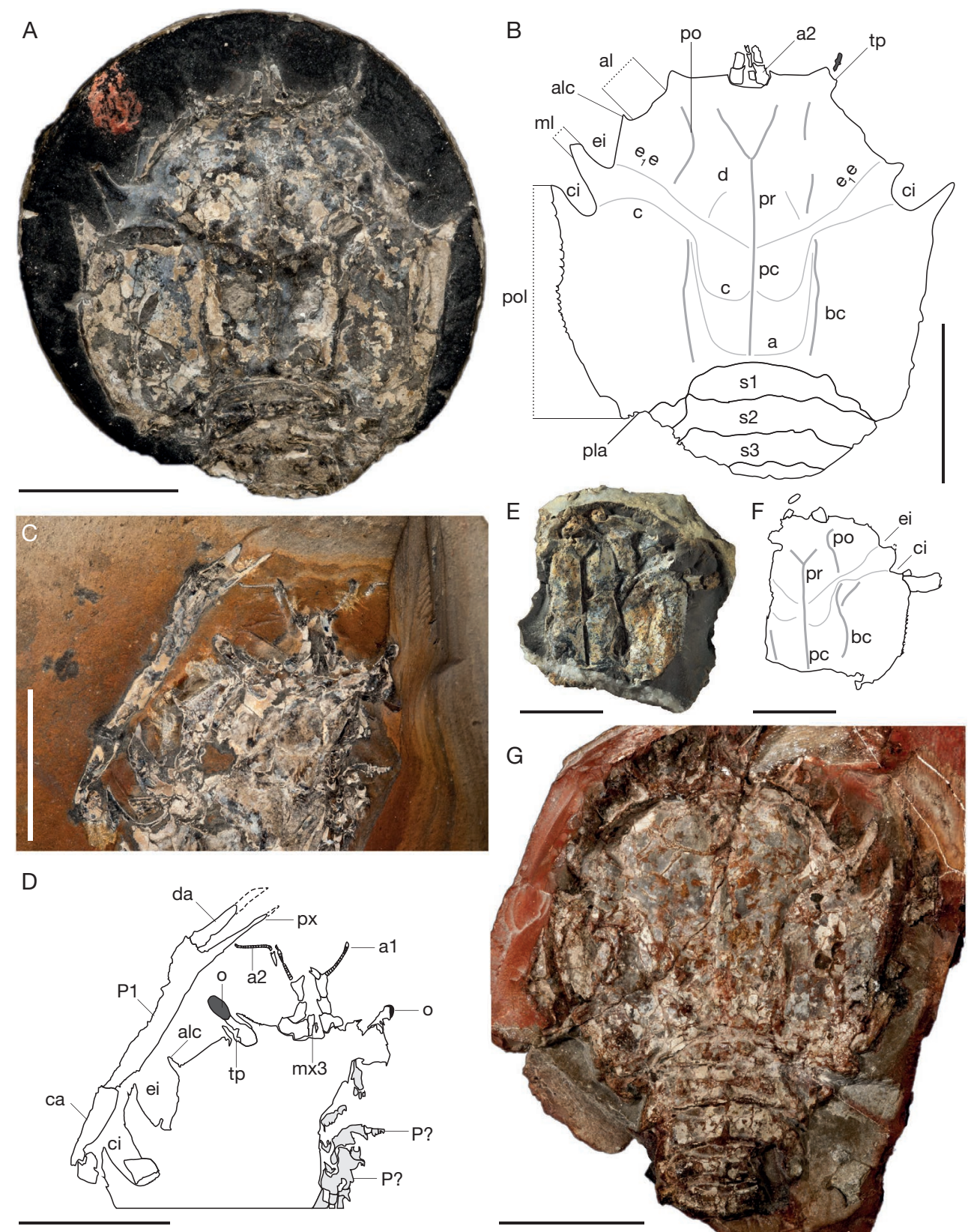

FIG. 3. - Eryon ellipticus Van Straelen, 1923: A, B, holotype UJF-ID.11540, dorsal view, cross-polarized light (A) and line drawing (B); C, D, FSL 170752, dorsal view in cross-polarized light (C) and line drawing (D); E, F, MNHN.F.A32534, inner view (E) and line drawing (F); G, MNHN.F.A00189, dorsal view in cross-polarized light; abbreviations: a; branchiocardiac groove; a1, antennula; a2, antenna; al, anterolateral margin; alc, anterolateral cervical spine; bc, branchial carina; c, postcervical groove; ca, first pereiopod carpus; ci, postcervical incision; $\mathbf{d}$, gastro-orbital groove; da, dactylus; $\mathbf{e}_{\mathbf{1}} \mathbf{e}$, cervical groove; ei, cervical incision; $\mathbf{m l}$, mediolateral margin; $\mathbf{M x 3}$, third maxilliped; o, eye; P1, first pereiopod; P?, indeterminate pereiopod; pc, postcervical carina; pla, posterolateral angle; po, postorbital carina; pol, posterolateral margin; pr, postrostral carina; px, pollex; s1-s3, pleonites 1-3; tp, tubular protrusion. Scale bars: 20 mm. Illustrations: A-D, F, G, D. Audo (MNHN); E, C. Lemzaouda (MNHN). 
duncle with three segments (short subtrapezoidal ischiocerite, subcylindrical merocerite, subtriangular carpocerite with enlarged distal margin) and multiarticulated flagellum of not assessable length attached to carpocerite; scaphocerite not preserved or absent.

\section{Thoracic appendages}

Chelate, long and slender first pereiopod, with a propodus about as long as carapace.

\section{Ornamentation}

Dorsal surface of exoskeleton covered by a few very small tubercles scattered on the surface.

\section{REMARKS}

Eryon ellipticus has always been ascribed to Eryon. However, since Eryon used to accommodate all fossil species of polychelidan lobsters, we justify herein the generic assignation of E. ellipticus. This species is ascribed to Eryon based upon its tubular protrusion of the anterolateral angle housing the eye peduncle, its large anterolateral cervical spine separating the anterolateral margin from the cervical incision, its mediolateral margin reduced to a very large spine and its well-marked branchial and postcervical carinae. All characters are similar to Eryon cuvieri, type species of Eryon. The scaphocerite appears to be missing. Although it is impossible to rule out that it was not preserved, it could be noted that scaphocerite is apparently also lacking in E. cuvieri. Eryon ellipticus can be distinguished from $E$. cuvieri by its marked cervical and postcervical grooves (very shallow in E. cuvieri), its longer ocular peduncle housed in a longer tubular protrusion, its larger visual surface, and its postcervical incisions which are wider toward the edge of the carapace (narrower in E. cuvieri) at the opening of the incision. Eryon ellipticus resembles E. sublevis by its marked cervical and postcervical grooves, but can easily be distinguished from this species by a wider frontal margin, more oblique tubular protrusion (oriented more anteriorly in E. sublevis) and smaller posterolateral spines. The holotype of E. sublevis is too incomplete to allow further comparisons. Eryon ellipticus is the stratigraphically oldest known occurrence of the genus in the fossil record.

\section{Genus Cycleryon Glaessner, 1965}

Cycleryon Glaessner, 1965: 116, pl. 1, fig. 5; 1969 : R470. - Schweigert 2001: 3. - Garassino \& Schweigert 2004: 244.

Macrourites - Schlotheim 1822: 35, 36, pl. 3, fig. 2 [pro parte].

Eryon-Lamarck 1838: 376, 377. — Münster 1839: 2, 3. - Pictet 1846:31, 32. — Oppel 1862: 8-10. — Woodward 1866: 494, 495 .

Cyclocaris - Beurlen \& Glaessner 1930: 64 (non Cyclocaris Stebbing, 1888).

ETYMOLOGY. - Not stated in original work from Glaessner (1965), undoubtedly a combination of the Greek

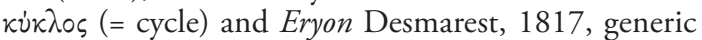
name for the first described species of Eryonoidea de Haan, 1841.

TYPE SPECIES. - Macrourites propinquus Schlotheim, 1822 , by original designation.

INCLUDED SPECIES. - Cycleryon propinquus (Schlotheim, 1822), C. orbiculatus (Münster, 1839), C. elongatus (Münster, 1839), C. wulfi Garassino \& Schweigert, 2004, C. bourseaui Audo, Charbonnier, Schweigert, Saint Martin 2014, C. romani n. sp.

EMENDED DIAGNOSIS. - Dorsoventrally flattened carapace with a subcircular outline in dorsal view, subcircular ocular incision, strengthened by orbital carina, deep cervical and postcervical incisions, postcervical incision deeper than cervical incision, straight or slightly convex anterolateral and mediolateral margins, carapace outline not confluent with that of pleon, uropodal exopod without diaeresis.

\section{REMARKS}

Eryon and Cycleryon share numerous characteristics: a large carapace with deep cervical and postcervical incisions, very shallow cervical and postcervical grooves and an absence of diaeresis on the uropodal exopod. For these reasons, species of these genera were mixed for a long time. For instance, Knebel (1907) classified all species now ascribed to Eryon and Cycleryon, and Knebelia schuberti to Eryon, within a group called "Eryonidae latiformes" (i.e. wide eryonid). The first attempt to discriminate these "wide eryonids" was made by Glaessner (1929), who ascribed E. elongatus, E. orbiculatus, E. spinimanus and E. propinquus to Coleia Broderip, 1835 probably based upon the general shape of the carapace. 
Finally, Beurlen \& Glaessner (1930) erected Cyclocaris to accommodate the species listed above. However, since Cyclocaris was preoccupied, Glaessner (1965) proposed the replacement name Cycleryon.

According to Glaessner (1965), Eryon and Cycleryon are clearly distinguished by the ocular incision separated from anterolateral angle (tubular protrusion in Eryon) and the straight mediolateral margin (reduced to a large spine in Eryon).

\section{Cycleryon romani $\mathrm{n} . \mathrm{sp}$.}

(Figs 2C; 4)

Coleia gigantea - Roman 1928: 109, pl. 3, fig. 1.

Coleia sp. 1 - Charbonnier 2009: 159, 226, fig. 395. Charbonnier et al. 2010: 115, 117.

Eтymology. - In honour to Frédéric Roman (18711943), French palaeontologist and specialist of ammonites at the University of Lyon. He published the first known illustration of this species (see Roman 1928: pl. 3, fig. 1), identifying it as Coleia gigantea (Van Straelen 1923).

TYPe MATERIAL. - Holotype: FSL 170522 (coll. Marin, part and counterpart, Fig. 4A, B). - Paratypes: UJF-ID.11546ab (coll. Gevrey, part and counterpart, Figs 4C-D), MNHN.F.A50712 (coll. Fischer), SMNS 66652 (Fig. 4E).

Type Locality. - Ravin des Mines, near La Boissine, La Voulte-sur-Rhône Lagerstätte, Ardèche, RhôneAlpes, France.

Type AGE. - Early Callovian, Gracilis ammonite Zone.

Additional SPECIMENS. - MNHN.F.A50728 (coll. Fischer, Fig. 4F).

DiAGNOSIS. - Dorsoventrally flattened carapace with subcircular outline; slightly concave frontal margin; large, deep, subrectangular cervical and postcervical incisions; slightly raised postorbital carina; shallow cervical and postcervical grooves; large and elongate first pereiopod.

\section{DESCRIPTION}

\section{Carapace outline}

Dorsoventrally flattened carapace with subcircular outline in dorsal view; slightly concave frontal margin, fringed by a row of tubercles; small subquadrate anterolateral angle; lateral margin with ocular, cervical, and postcervical incisions; subcircular ocular incision; slightly rounded anterolateral margin with few small anterolateral spines, oblique to longitudinal axis; anterolateral cervical spine larger than other anterolateral spines; large and deep subrectangular cervical incision; straight mediolateral margin, shorter than anterolateral margin, with a few spines; large and deep subrectangular postcervical incision, deeper than cervical incision; slightly rounded posterolateral margin, with large spines curved forward; subquadrate posterolateral angle, not contiguous to pleon; deeply concave posterior margin.

\section{Carapace carinae and grooves}

Postrostral and postcervical carinae raised, marked by a row of tubercles on each side, not separated by cervical groove; short and raised postrostral carina extending on the posterior half of cephalic region, anteriorly connected to a large area with a coarse tubercle ornamentation widening anteriorly, marked by a row of tubercles on each side; raised postcervical carina, connected to postrostral carina and ornamented by a row of tubercles decreasing in size posteriorly on each side; branchial carina cut by cervical groove, curving inward anteriorly, slightly sinuous posterior to postcervical groove, slightly raised and marked by a row of tubercles; posterior margin strengthened by carina, cut by postcervical carina, raised and marked by a row of large tubercles; very shallow cervical groove extending from cervical incision to reach median line without cutting it; shallow postcervical groove extending from postcervical incision to reach branchial carina, cut by branchial carina, oblique between branchial and postcervical carinae, curving forward before reaching without cutting postcervical carina; short gastroorbital groove, extending anteriorly from cervical groove between postorbital and postrostral carinae.

\section{Pleon}

Pleon half as wide as carapace; subrectangular, smooth s1 tergum shorter than the others; subrectangular s2-s3 terga, with a pair of transverse grooves converging medially and a short median carina, with an anterior spine, cutting posterior transverse groove; subrectangular $s 4-55$ terga, with a pair of transverse grooves converging medially and a short median carina cutting posterior transverse groove; 
elongate $s 1$ tergopleuron, with a small axial process at the fold separating tergopleuron from tergum; s2 tergopleuron poorly preserved, with small axial process at the fold separating tergopleuron from tergum; s3-s4 tergopleura hooked, with small axial process at the fold separating tergopleura from terga.

\section{Eyes and cephalic appendages}

Small eye, entirely contained within ocular incision; antennula with wide basipodite carrying long and slender outer flagellum (exopodite) and endopodite consisting of at least two enlarged podomeres carrying a large flagellum of inaccessible length (at least as long as antennal peduncle); antenna composed of wide subtriangular basipodite, carrying slender fusiform scaphocerite (exopodite) and endopodite with subtriangular first podomere, cylindrical second podomere and distal part forming small flagellum.

\section{Thoracic appendages}

Chelate, large and elongate first pereiopod, with a propodus about as long as carapace and a stout, subtriangular carpus; poorly preserved, short, achelate fifth pereiopod.

\section{Ornamentation}

Carapace with coarse and dense cover of tubercles on the cephalic region anterior to postrostral carina, thinner and scattered on the rest of the carapace, almost lacking between branchial carinae.

\section{REMARKS}

Cycleryon romani $\mathrm{n}$. sp. is ascribed to Eryonidae based upon the wide, dorsoventrally flattened, carapace not confluent in outline with that of the pleon and axial carina on pleonal terga cutting posterior transverse groove. It is ascribed to Cycleryon based upon of the subcircular carapace, the carinate ocular incision, the deep cervical and postcervical incisions (postcervical incision deeper), the slightly convex anterolateral margin, and the straight mediolateral margin. $C y$ cleryon romani $\mathrm{n}$. sp. differs from all other species of Cycleryon by its deeper, subrectangular cervical and postcervical incisions. In addition, a very small specimen MNHN.F.A50728 (Fig. 4F) possessing a similar shape of carapace and a short $\mathrm{P} 1$ propodus is tentatively ascribed to Cycleryon romani $\mathrm{n}$. sp.

\section{Genus Voulteryon n. gen.}

ETYMology. - Combination of La Voulte-sur-Rhône (type locality) and Eryon Desmarest, 1817, generic name for the first described species of Eryonoidea. The gender of the genus is masculine.

TYPE SPECIES. - Voulteryon parvulus n. sp. by monotypy.

INCLUDED SPECIES. - Only the type species is known.

DiAgNosis. - As for type species.

\section{DISCUSSION}

All studied specimens referred to Voulteryon n. gen. are probably juveniles; a possible adult specimen is figured by Charbonnier (2009: fig. 404) as a Willemoesiocaris ovalis, but is not accessible to scientific enquiry. Voulteryon n. gen. is ascribed to Eryonidae on the basis of the deep cervical and postcervical incisions (as in Eryon, Cycleryon, Soleryon, Rosenfeldia and Tethyseryon), the cervical groove not cutting median line (as in Eryon, Cycleryon, and possibly in Soleryon), and the axial carina cutting posterior transverse groove on s2 to s5 terga (as in Eryon, Cycleryon, Knebelia, Soleryon, and Rosenfeldia). Carapace is also not confluent in outline with pleon, a character shared in all Eryonidae. However, this character is also documented for many juvenile polychelidan specimens such as those of Palaeopentacheles (Audo et al. 2014b: fig. 6D) and in extant eryoneicus larvae (Bernard 1953; Martin 2014). It may correspond to the retention of an ancestral juvenile character in Eryonidae and therefore cannot be taken into account. Voulteryon n. gen. differs from Eryon, Cycleryon, Soleryon and Rosenfeldia in having a shallow ocular incision (deep in all aforementioned genera) and narrower carapace (broad in all aforementioned genera), from Knebelia by its deeper cervical and postcervical incisions (shallow in Knebelia), unsegmented frontal margin (with frontal lobes in Knebelia), from Tethyseryon in having an axial carina cutting posterior transverse groove on $\mathrm{s} 2$ to 55 (carina cut by posterior transverse groove in Tethyseryon) and its narrower carapace (broader in Tethyseryon). 

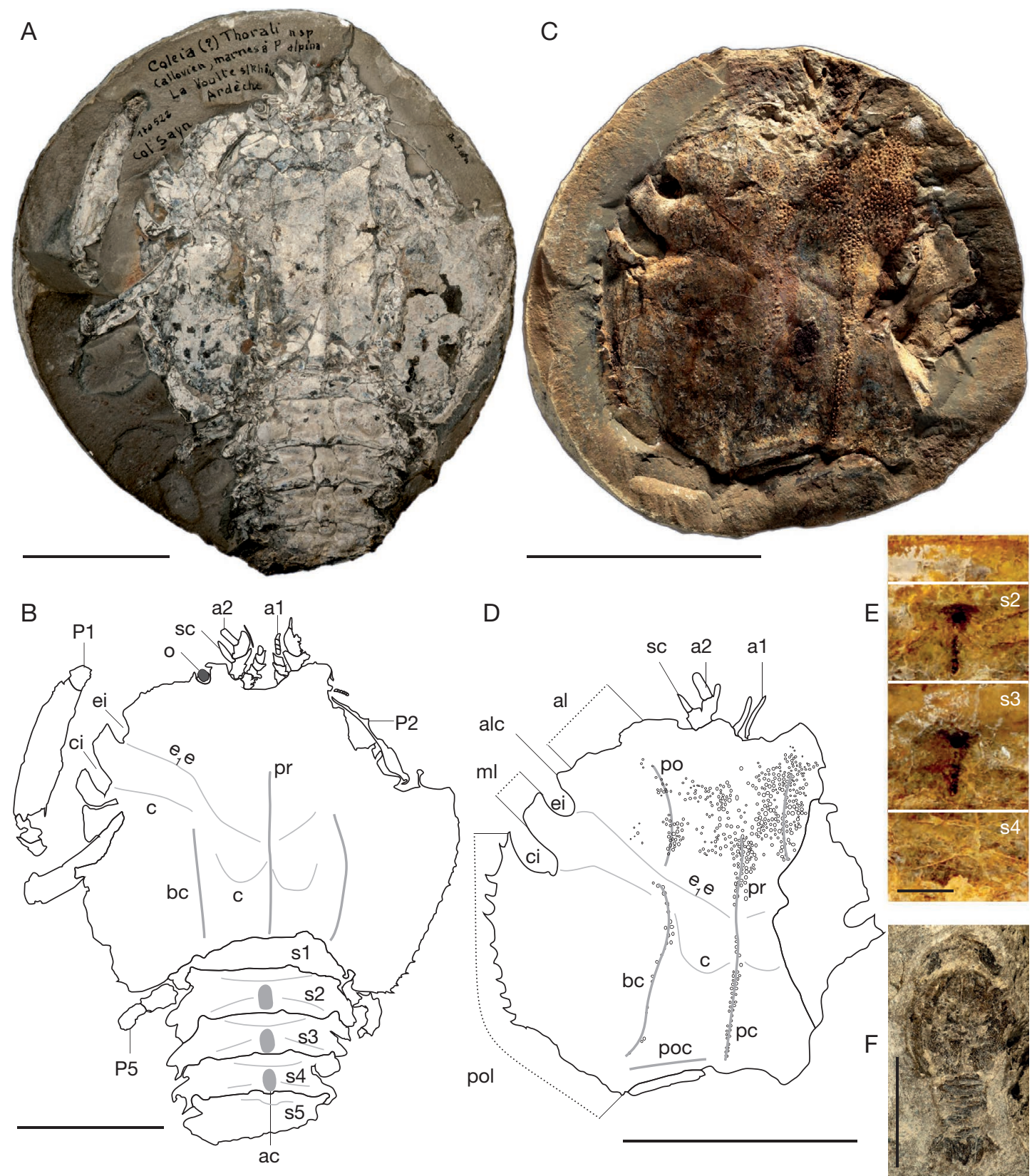

FIG. 4. - Cycleryon romani n. sp.: A, B, holotype FSL.170522, cross-polarized light (A) and line drawing (B); C, D, paratype UJFID.11546, cross-polarized light (C) and line-drawing (D); E, paratype SMNS 66652, detail of the counterpart showing the axial carina on pleonal terga; F, MNHN.F.A50728, cross-polarized light. Abbreviations: a1, antennula; a2, antenna; ac, axial carina; al, anterolateral margin; alc, anterolateral cervical spine; bc, branchial carina; c, postcervical groove; ci, postcervical incision; $\mathbf{e}_{1} \mathbf{e}$, cervical groove; ei, cervical incision; $\mathbf{m l}$, mediolateral margin; o, eye; P1-P5, pereiopods 1-5; pc, postcervical carina; po, postorbital carina; poc, posterior carina; pol, posterolateral margin; pr, postrostral carina; s1-s5, pleonites 1 to 5; sc, scaphocerite. Scale bars: A, D, 50 mm; E, 5 mm; F, 10 mm. Illustrations: A, B, D-F, D. Audo (MNHN); C, C. Lemzaouda (MNHN). 
Voulteryon parvulus n. sp.

(Fig. 2F; 5)

Willemoesiocaris ovalis - Charbonnier 2009: 228, fig. 404.

"Very small-sized Eryonoidea" - Charbonnier et al. 2010: 127, fig. 11d.

ETYMOLOGY. - From the Latin parvulus for "very small" or "very young", alluding to the small size of the studied specimens, which may correspond to juvenile stages of this new species.

TYPE MATERIAL. — Holotype: MNHN.F.A50708 (Figs 5AE). - Paratype: MNHN.F.A29151 (Fig. 5F).

Type locality. - Ravin des Mines, near La Boissine, La Voulte-sur-Rhône Lagerstätte, Ardèche, RhôneAlpes, France.

TYPE AGE. - Early Callovian, Gracilis ammonite Zone.

DiAgnosis. - Slightly bulbous, dorsoventrally flattened carapace, with ovoid outline in dorsal view; rounded anterolateral angle armed with long spines; shallow ocular incision; deep cervical and postcervical incisions; large anterolateral cervical spine; cervical groove not cutting median line; pair of large, slightly convex, disc-shaped structures on each side of postcervical carina, at mid-distance between postcervical groove and posterior margin; axial carina cutting posterior transverse groove on s2-s5; lanceolate s2-s5 tergopleura.

\section{DESCRIPTION}

\section{Carapace outline}

Slightly bulbous, dorsoventrally flattened carapace, with ovoid outline in dorsal view; concave and angular serrated frontal margin; short and rounded anterolateral angle armed with long spines; lateral margin with ocular, cervical and postcervical incisions; ocular incision placed at the distal extremity of a short protrusion housing ocular peduncle, sinuous in outline; slightly rounded anterolateral margin separated from cervical incision by a large and curved anterocervical spine; deep triangular cervical incision; straight mediolateral margin, shorter than anterolateral margin; deep postcervical incision, narrower at the opening; straight posterolateral margin, with small sharp spines; subquadrate and rounded posterolateral angle not contiguous to pleon; slightly concave posterior margin.

\section{Carapace carinae and grooves}

Postrostral and postcervical carinae not separated by cervical groove; raised postrostral carina flanked by a row of pits (poorly preserved, eroded tubercles?) on each side and extending on the posterior half of cephalic region; raised postcervical carina flanked by a row of tubercles on each side; raised branchial carina, extending and curving outward on posterior half of cervical region, curving inward between cervical and branchial regions, cut by cervical and postcervical grooves, extending backward and slightly outward posteriorly; deep cervical groove extending from cervical incision, cutting branchial carina reaching median line without cutting it; deep postcervical groove extending from postcervical incision to median line, effaced near branchial carina, and curving forward before reaching median line without cutting it; very faint branchiocardiac groove extending from postcervical groove, along the branchial carina anteriorly, curving inward posteriorly to reach median line; shallow gastro-orbital groove extending obliquely from cervical groove near branchial toward postrostral carina; pair of large, slightly convex, disc-shaped structures on each side of postcervical carina, at mid-distance between postcervical groove and posterior margin.

\section{Pleon and telson}

Pleon about as long as carapace, about half as wide as carapace; short s1 tergum, badly preserved; s2-s5 with subrectangular terga bearing two transverse grooves converging medially, and axial carina, marked by a pair of rows of tubercles, stretching from behind anterior transverse groove, cutting the posterior one and reaching posterior margin; s2-s5 with lanceolate tergopleura.

\section{Eyes and cephalic appendages}

Large spherical eyes, slightly projected from ocular incision; cephalic appendages poorly preserved.

\section{Thoracic appendages}

Large first pereiopod with a short carpus and a long propodus, poorly preserved. - Pleonal appendages: only poorly preserved uropods. 

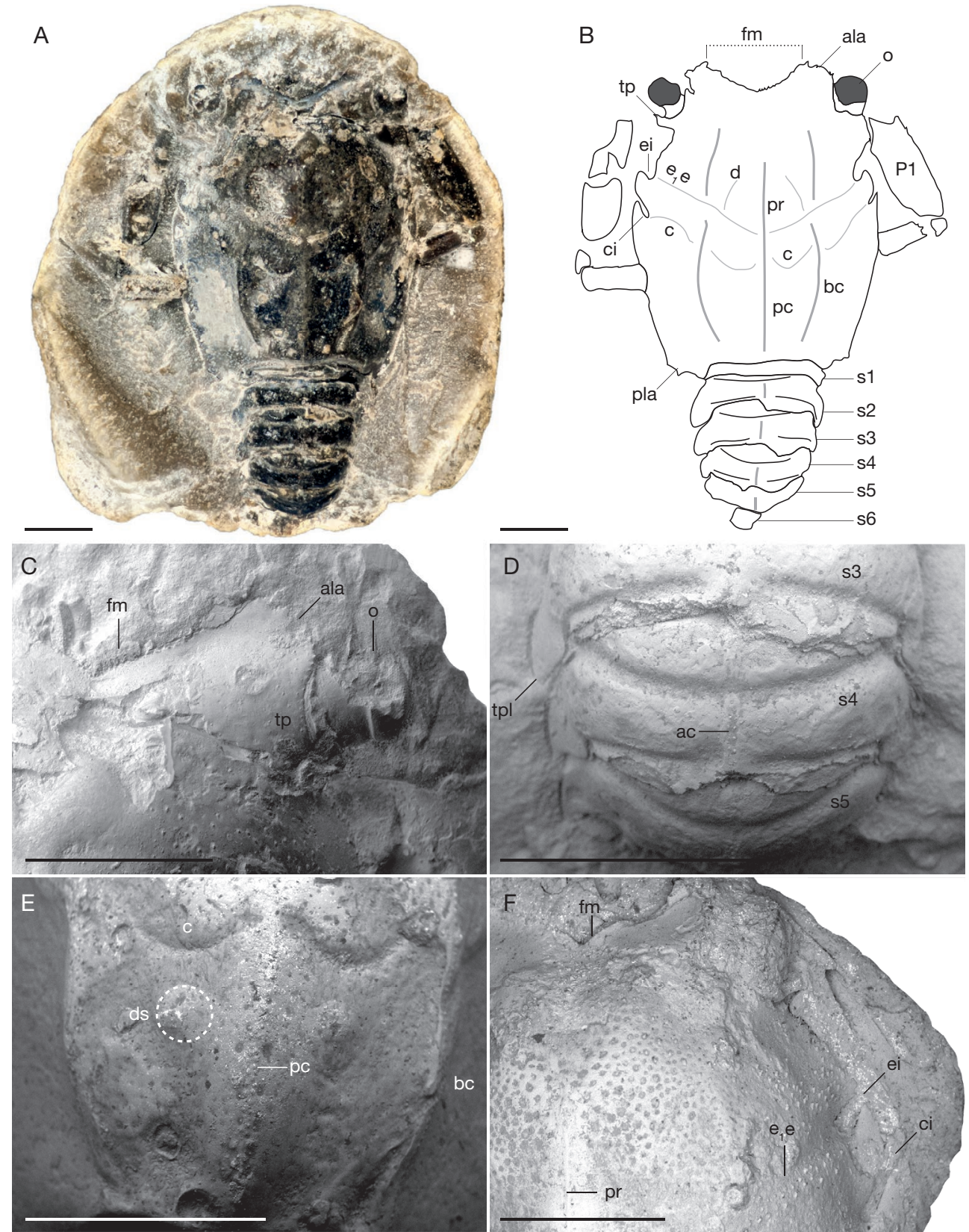

FIG. 5. - Voulteryon parvulus n. gen., n. sp.: A-E, holotype MNHN.F.A50708, cross-polarized light (A), line drawing (B), SEM picture of right anterior portion of the carapace showing the eye and anterior margin (C), SEM picture of the pleon showing the lanceolate tergopleura (D), SEM picture of posterior part of carapace showing the disk-shaped structures (E); $\mathbf{F}$, paratype MNHN.F.A29151, SEM picture showing the deep cervical and postcervical incisions. Abbreviations: ac, axial carina of pleonal tergum; ala, anterolateral angle; bc, branchial carina; c, postcervical groove; ci, postcervical incision; $\mathbf{e}_{1} \mathbf{e}$, cervical groove; ei, cervical incision; d, gastro-orbital groove; ds, disk-shaped structure; fm, frontal margin; o, eye; P1, first pereiopod; pc, postcervical carina; pr, postrostral carina; s1-s6, pleonites 1-6; tp, tubular protrusion; tpl, tergopleura. Scale bars: 2 mm. Illustrations: D. Audo. 


\section{Ornamentation}

Dorsal surface of carapace covered by pits, flanks covered by small spines; pits probably correspond to eroded spines.

\section{REMARKS}

All available and studied specimens are small (about $15 \mathrm{~mm}$ ). A large specimen (about $11 \mathrm{~cm}$ ) misidentified as Willemoesiocaris ovalis by Charbonnier (2009: 228, fig. 404) possesses a roughly similar morphology and might be assigned to $V$. parvulus n. gen., n. sp. (adult specimen?).

\section{Family ColeIIDAE Van Straelen, 1925}

Type genus. - Coleia Broderip, 1835.

InCluded Genera. - Coleia Broderip, 1835, Pseudocoleia Garassino \& Teruzzi, 1993, Proeryon Beurlen, 1928, Willemoesiocaris Van Straelen, 1923.

EMENDED DiAgNOSIs. - Sharp anterolateral angle forming the anterior margin of ocular incision; widely open (i.e. hemicircular to "U-shaped") ocular incision; well-developed eye projecting from ocular incision; wellmarked cervical groove curving backward near median line; uropodal exopod with curved diaeresis; third maxilliped with enlarged ischium.

\section{REMARKS}

Coleiidae is a large family, mostly due its type genus Coleia, to which twenty species are currently ascribed (Schweitzer et al. 2010). A quick examination of Coleia shows it is probably a waste-basket genus since it includes species varying greatly in morphology. However, the problems with coleiids are not confined to Coleia. Indeed, Van Straelen (1925) defined rather loosely the family as polychelidans with a diaeresis on the uropodal exopod, ocular incisions and always a scaphocerite. This definition is quite problematic: 1) ocular incisions are shared by all extant and fossil polychelidans (except in Eryon, in which the incision is modified in tubular protrusion); 2) the scaphocerite is probably only missing in Eryon; and (3) the presence of a diaeresis occurs in multiple decapod crustaceans (dendrobranchiate shrimps, carideans, and many groups of reptantians), this character distribution is therefore difficult to assess, and it could, in fact, be plesiomorphic for polychelidan lobsters.
Ahyong (2009) proposed the first phylogenetic analysis including fossil and extant polychelidans. Unfortunately, for the Coleiidae, Ahyong (2009) did not consider Coleia antiqua (type species of Coleia, type genus of the family) but based his analysis upon Palaeopolycheles longipes (Fraas, 1855), which was then considered to be a member of Coleia (Schweigert \& Dietl 1999). He provided a new definition of Coleiidae based on the following characters: U-shaped ocular incision, well-developed eye directed laterally, postorbital carina aligned with branchial carina, cervical and postcervical grooves marked across carapace, shallow cervical and postcervical incisions, and second and third pleonites tergopleura identical (i.e. s2 tergopleuron not saddle-shaped).

However, it shall be noted that: 1) U-shaped ocular incisions occur also in Palaeopentacheles roettenbacheri (Münster, 1839) (Palaeopentachelidae); 2) cervical and postcervical grooves marked across carapace occur in Eryon ellipticus, Soleryon amicalis Audo, Charbonnier, Schweigert \& Saint Martin, 2014, S. schorri Audo, Charbonnier, Schweigert \& Saint Martin, 2014 (see Audo et al. 2014a) and Knebelia totoroi Audo, Schweigert \& Charbonnier, 2014 (see Audo et al. 2014b); and 3) identical s2-s3 tergopleura are reported from most polychelidans but polychelids and two closely allied fossil species (see discussion on stem polychelidae). Moreover, both $C$. antiqua and $P$. longipes show clearly deep cervical and postcervical incisions, though the diagnosis proposed by Ahyong (2009) stated that cervical and postcervical incisions are shallow in Coleiidae.

For these reasons, it is still difficult to precisely define Coleiidae. We propose herein to include within Coleiidae polychelidan lobsters with 1) a sharp anterolateral angle forming the anterior margin; 2) a widely open (i.e. hemicircular to "U-shaped") ocular incision; 3) a well-developed eye; 4) a well-marked cervical groove curving backward near median line; 5) uropodal exopod with a curved diaeresis; and 6) a third maxilliped with enlarged ischium. This definition is temporary. Indeed, these characters may reveal plesiomorphic or even non-informative, but they seem to be quite representative of Coleiidae, including Coleia antiqua, in its modern conception (Schweitzer et al. 2010). Only a new phylogenetic analysis including a large number of coleiids may allow defining properly this family. 
Genus Proeryon Beurlen, 1928.

Proeryon Beurlen, 1928: 191-193. - Glaessner 1929: 339; 1969: R470.

Eryon - Lamarck 1838: 376-377. - Oppel 1862: 8-10. - Woodward 1866: 494-495

Coleia - Van Straelen 1925: 132-134.

ETYMology. - Not stated in original work by Beurlen (1928), undoubtedly a combination of the Greek prefix

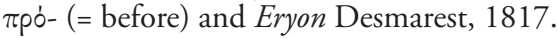

TYPE SPECIES. - Eryon hartmanni Meyer, 1836, subsequent designation by Glaessner (1929). According to Beurlen (1928), the holotype of this species is lost but we examined a good cast from the d'Orbigny collection (MNHN.F.A02720).

INCLUDED SPECIES. - Proeryon hartmanni (Meyer, 1836); P. hauffi Beurlen, 1944; P. laticaudatus Beurlen, 1928; $P$. zehentbaueri nomen novum pro P. giganteus Beurlen, 1930 non Eryon giganteus Van Straelen, 1923; P. giganteus (Van Straelen, 1923).

DiAGNOSIS. - Dorsoventrally flattened carapace; large, slightly concave anterior margin; wide hemicircular ocular incisions; rounded posterolateral angle, extending along pleon; cervical groove curving backward near median line; cervical and postcervical grooves almost parallel between lateral margin and branchial carina; posterior transverse groove on pleonal tergites cutting median line; uropodal exopod with very curved diaeresis.

\section{REMARKS}

Knebel (1907) was the first to attempt to divide polychelidan fossils into two groups: "Eryonidae latiformes" (with a wide carapace) and "Eryonidae augustiformes" (with a narrow carapace). This work was based only on Late Jurassic polychelidan lobsters from Germany and did not take into account Early Jurassic species. Based upon Toarcian species, Beurlen (1928) considered Knebel's divisions to be artificial and proposed Proeryon, which he thought to be ancestor of "Late Jurassic species" - probably referring to Eryonidae sensu stricto. Moreover, he considered Coleia Broderip, 1835 to be more primitive. Shortly, Beurlen (1928) considered a Proeryon-group lacking a diaeresis on the uropodal exopod and a Coleia-group with a diaeresis being present.
Contrary to Beurlen (1928), we pointed out that Proeryon hartmanni (type species) and all the species herein included in Proeryon do possess a diaeresis on the uropodal exopod.

Proeryon also possesses a sharp anterolateral angle forming anterior margin of ocular incision, a hemicircular ocular incision, a well-developed eye projecting from ocular incision, and a third maxilliped with wide ischium; all these characters being similar to Coleia antiqua. For these reasons and according to Glaessner (1969), we maintain Proeryon in Coleiidae. However, a complete revision of this family will be required to affirm or infirm this assignment.

\section{Proeryon giganteus (Van Straelen, 1923)} (Figs 2D-E; 6; 7)

Eryon giganteus Van Straelen, 1923: 91, fig. 8. — Balss 1924: 175 .

Coleia gigantea - Van Straelen 1925: 145-147, fig. 66, pl. 3, figs 3, 4, pl. 4, figs 1, 2. - Roman 1928: 109, fig. 18, pl. 3, fig. 4 (non fig. 1). - Glaessner 1929: 127. - Charbonnier 2009: 158, 159, 163, figs 236, 244, 224-229, 393, 394, 399-401. - Charbonnier et al. 2010: 115-117, figs 3c, 4c, 11a-c.

Cyclocaris giganteus - Pinna 1968: 103.

Cycleryon gigantea (sic) - Fischer 2003: 241, fig. 27 (genus also misspelled Glycerion and Cyclerion).

Cycleryon giganteus - Garassino \& Schweigert 2006: 26.

Proeryon giganteus - Schweitzer et al. 2010: 44.

ETymology. - Not indicated in original description, probably referring to the fact this was the largest species described from La Voulte by Van Straelen (1923).

TyPe MATERIAL. - Lectotype (UJF-ID, coll. Gevrey), designation by Van Straelen (1925) after ICZN (1999: article 74.5); not found in the collections of Institut Dolomieu. — Eight paralectotypes (Gevrey coll.): UJFID.11547, 11548 (Fig. 7B), 11549 (part and counterpart), 11550, 11552, 14023 (Figs 6A-C), 14047-14049 (part and counterpart), 14051, 14052 (Figs 7C-D), 15050.

TyPE LOCAlity. - Ravin des Mines, near La Boissine, La Voulte-sur-Rhône Lagerstätte, Ardèche, RhôneAlpes, France. 
TYPE AGE. - Early Callovian, Gracilis ammonite Zone.

ADDiTIONAL EXAMINED MATERIAL. - FSL 170521, 170603, 170607-170609 (coll. Marin), 170610 (coll. Caillet), 710080-71081 (coll. Charbonnier). — MHNGr. PA.10203, 10276. - MNHN.F.A50710, A50713, A50714 (Fig. 7A), A50715, A50716, A50717, A50718, A50719, A50720, A50726, A50727, A50730, A50741 (coll. Fischer), B11759, R03515 (cast). — MSNM.i20703 (Fig. 6D). - UJF-ID.14020, 14026 - UPMC-248.

DiAGNOSIS. - Dorsoventrally flattened carapace, with pyriform outline in dorsal view; wider than long; small and triangular cervical and postcervical incisions; straight, elongate branchial carina, not merged to postorbital carina; posterior transverse groove on pleonal terga cutting axial carina; wide, ovoid, flattened scaphocerite; first pereiopod extremely long and slender; uropodal exopod with curved diaeresis.

\section{DESCRIPTION}

\section{Carapace outline}

Dorsoventrally flattened carapace, with pyriform outline in dorsal view, wider than long; slightly concave frontal margin; anterolateral angle forming a large spine; lateral margin incised by ocular, cervical and postcervical incisions; large and hemicircular ocular incision; slightly rounded anterolateral margin with a few small spines, oblique compared to longitudinal axis; anterolateral cervical spine as large as the other anterolateral spines; small, triangular, narrow cervical incision; straight mediolateral margin, longer than anterolateral margin, with a few small spines; small, triangular postcervical incision, smaller than cervical one; rounded posterolateral margin, fringed with small spines; rounded posterolateral angle, extending along pleon; wide, only slightly concave posterior margin.

\section{Carapace carinae and grooves}

Postrostral and postcervical carinae separated by cervical groove; postrostral carina raised on the posterior half of cervical region, ornamented by a single row of large tubercles; postcervical carina raised and ornamented by a single row of tubercles, cut by postcervical groove; raised postorbital carina, extending onto the anterior half of cephalic region, parallel and separated from the anterior portion of branchial carina; straight and long branchial carina, cut by cervical and postcervical grooves, raised and ornamented by tubercles; longitudinal lateral carina; deep and oblique cervical groove, stretching from cervical incision, cutting branchial carina, curving backward near median line, cutting median line and separating postrostral and postcervical carinae around half of the carapace length; deep postcervical groove, transverse between postcervical incision and branchial carina, shallow, curving backward and then forward between branchial and postcervical carinae, cutting postcervical carina; shallow branchiocardiac groove extending from the postcervical groove, on the inner side of branchial carina, curving toward median line; short gastroorbital groove, extending obliquely from cervical groove toward postrostral carina.

\section{Pleon and telson}

Pleon half as wide and slightly longer (telson excluded) than carapace; subrectangular s1 tergum shorter than others, with a pair of transverse grooves converging medially; subrectangular s2-s5 terga, with two transverse grooves, anterior one deeper and separated from anterior margin by a slightly inflated region, large median tubercle between both grooves and smaller one after posterior transverse groove; subtrapezoidal $s 6$ tergum, with two transverse grooves, anterior one deeper and separated from anterior margin by a slightly inflated region, large median tubercle between both grooves; subtriangular and elongate $s 1$ tergopleuron with a small axial process at the fold separating tergopleuron from tergum; subtriangular s2-s3 tergopleura with a spine curving forward in the middle of lateral margin, with a small axial process at the fold separating tergopleura from terga; s4-s6 tergopleura poorly preserved, with a small axial process at the fold separating tergopleura from terga; subtriangular telson, strengthened by two longitudinal carinae, with bulged anterior median region and a short median distal groove.

\section{Eyes and cephalic appendages}

Large eye, slightly projected from of ocular incision; antennula poorly preserved, with a long flagellum of unassessable length; antenna composed of a triangular basipodite carrying: 1) a wide, ovoid and flattened scaphocerite with a spiny distal margin, and ornamented by a few fine tubercles; and 2) an 

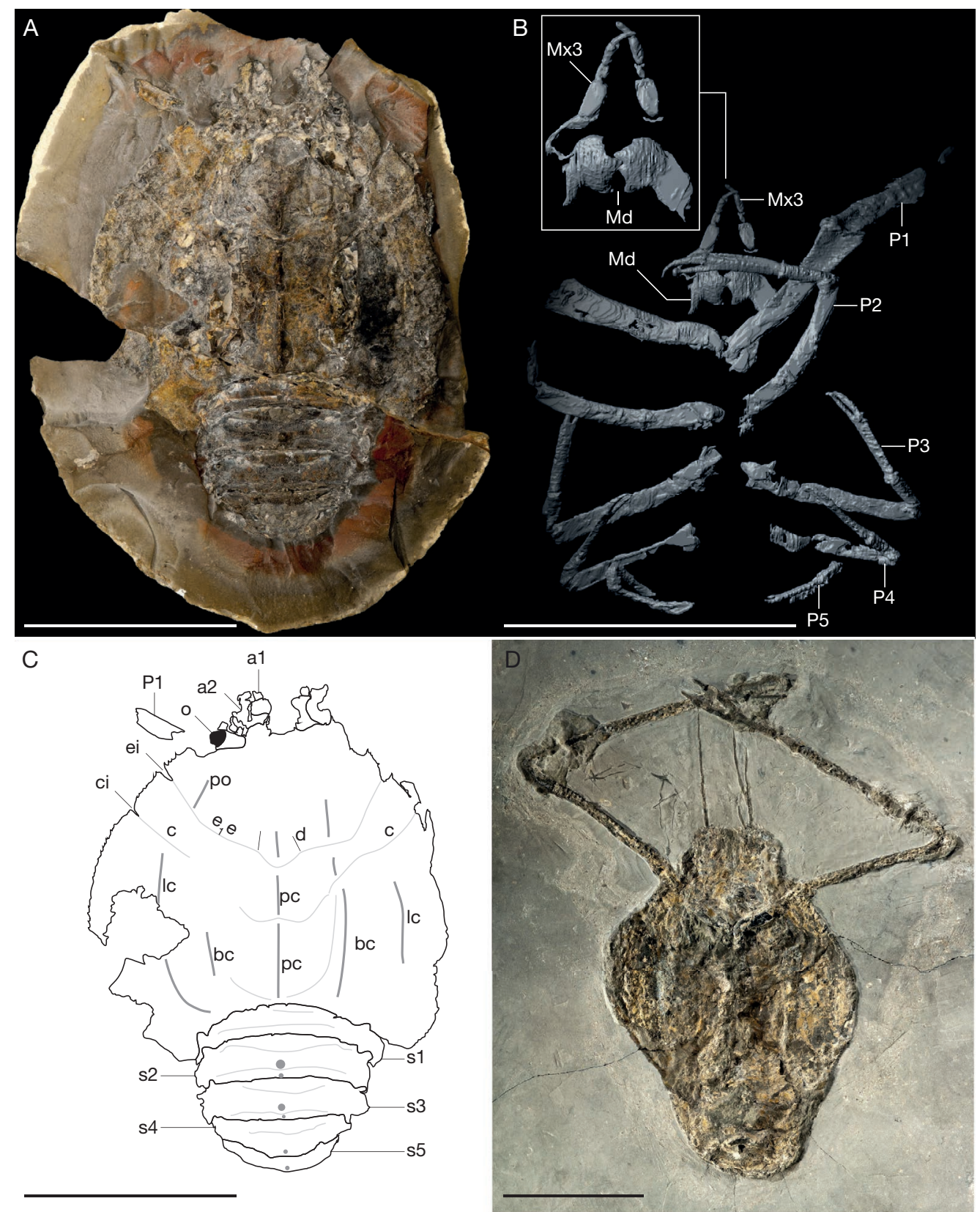

FIG. 6. - Proeryon giganteus (Van Straelen, 1923): A-C, paralectotype UJF-ID.14023, cross-polarized light (A), model reconstructed from CT-scan radiographies (B) and line drawing (C), D, MSNM.i20703, cross-polarized light. Abbreviations: a1, antennula; a2, antenna; bc, branchial carina; ci, postcervical incision; c, postcervical groove; d, gastro-orbital groove; $\mathbf{e}_{1} \mathbf{e}$, cervical groove; ei, cervical incision; Ic, lateral carina; o, eye; md, mandible; Mx3, third maxilliped; P1-P5, pereiopods 1 to 5; pc, postcervical carina; po, postorbital carina; pr, postrostral carina; s1-s5, pleonites 1 to 5 . Scale bars: 50 mm. Illustrations: D. Audo (MNHN). 
endopodite composed of two large articles, each forming a leaf-like inner expansion and carrying a long flagellum at least as long as $2 / 3$ of carapace; mandibles with long subtriangular apodemes, and a hemicircular thicker mesial part forming a few triangular teeth of uneven sizes.

\section{Thoracic appendages}

$\mathrm{Mx} 3$ with large hemicircular ischium bearing finely serrated crista dentata and ending by four short subcylindrical podomeres; chelate, very long and slender P1 with: 1) slender dactylus; 2) propodus about as long as carapace and three times as long as dactylus; 3) elongated carpus; 4) elongate merus slightly shorter than propodus and slightly widening distally; and 5) short and curved ischium; chelate P2-P4 decreasing in size posteriorly, each with distally curved dactylus, three times shorter than propodus, and pollex slightly curved distally; chelate P5 with short subtriangular carpus, long and slender propodus and short dactylus and pollex.

\section{Pleonal appendages}

Slender and falciform petasma (first pleopod modified into a male copulatory appendage); uropod composed of a subrectangular basipodite carrying: 1) large exopod with rounded distal margin, lateral and longitudinal carinae and very curved diaeresis between those carinae, at about three quarters of exopod length; and 2) large endopod, with rounded distal margin and wide median carina distally effaced.

\section{Ornamentation}

Densely and finely tuberculate exoskeleton.

\section{REMARKS}

\section{Systematic position}

Systematic position of Eryon giganteus Van Straelen, 1923 has been subject of debates linked to the fact that when the species was described, most species were still ascribed to a single genus, Eryon, following the works by Oppel (1862), Woodward (1866, 1881, 1911) and Knebel (1907). Besides, the figure proposed by Van Straelen (1923) is misleading because it seems to be based upon composite material. Van Stralen's reconstruction shows subcircular ocular incisions typical of Cycleryon, but unknown in Coleia or Proeryon. Van Straelen (1925) subsequently ascribed the species to Coleia due to the presence of a diaeresis and was followed by numerous successive authors such as Roman (1928), Glaessner (1929), Charbonnier (2009) and Charbonnier et al. (2010). However, Pinna (1968) placed the species in Cyclocaris then renamed Cycleryon by Glaessner (1965). This position, mainly due to Van Straelen's figure and to the subcircular shape of the carapace, was followed by Fischer (2003) and Garassino \& Schweigert (2006). Finally, Schweitzer et al. (2010) proposed the new assignment to Proeryon but without any justifications.

We concur with the assignment to Proeryon. This assignment is based upon the wide hemicircular ocular incision, the small cervical and postcervical incisions, the cervical groove curving backward near median line, the pleonal terga with posterior transverse groove cutting axial carina, and the uropodal exopod with strongly curved diaeresis. All these characters are diagnostic of Proeryon. Proeryon giganteus differs from other species of Proeryon in having very long and slender first pereiopods (stouter in all other species), a wider carapace, and a lateral carina on branchial region.

\section{Nomenclatural treatment}

Schweitzer et al. (2010) synonymized Proeryon laticaudatus Beurlen, 1928 with P. giganteus Beurlen, 1930 without any justification. Examination of the types specimens of $P$. giganteus (holotype by monotypy, coll. Hauff) and of Proeryon laticaudatus (two syntypes, coll. Hauff) lead us to a different conclusion. Proyeron giganteus Beurlen, 1930 shows a pyriform carapace, a broad pleon and a short anterolateral angle while in P. laticaudatus, the carapace is ovoid, the pleon is narrower and the anterolateral angle is elongate. For these reasons, we consider $P$. giganteus and $P$. laticaudatus as separate species. Consequently, this situation leads to a case of secondary homonymy. To solve this problem and according to ICZN (1999: articles 53.3, 57.3), we propose herein the replacement name $P$. zehentbaueri pro $P$. giganteus Beurlen, 1930 non P. giganteus (Van Straelen, 1923). The specific epithet zehentbaueri is in honour of Michael Zehentbauer (Kösching, Bavaria, Germany), who donated important decapod crustacean material to the SNMS collection. 

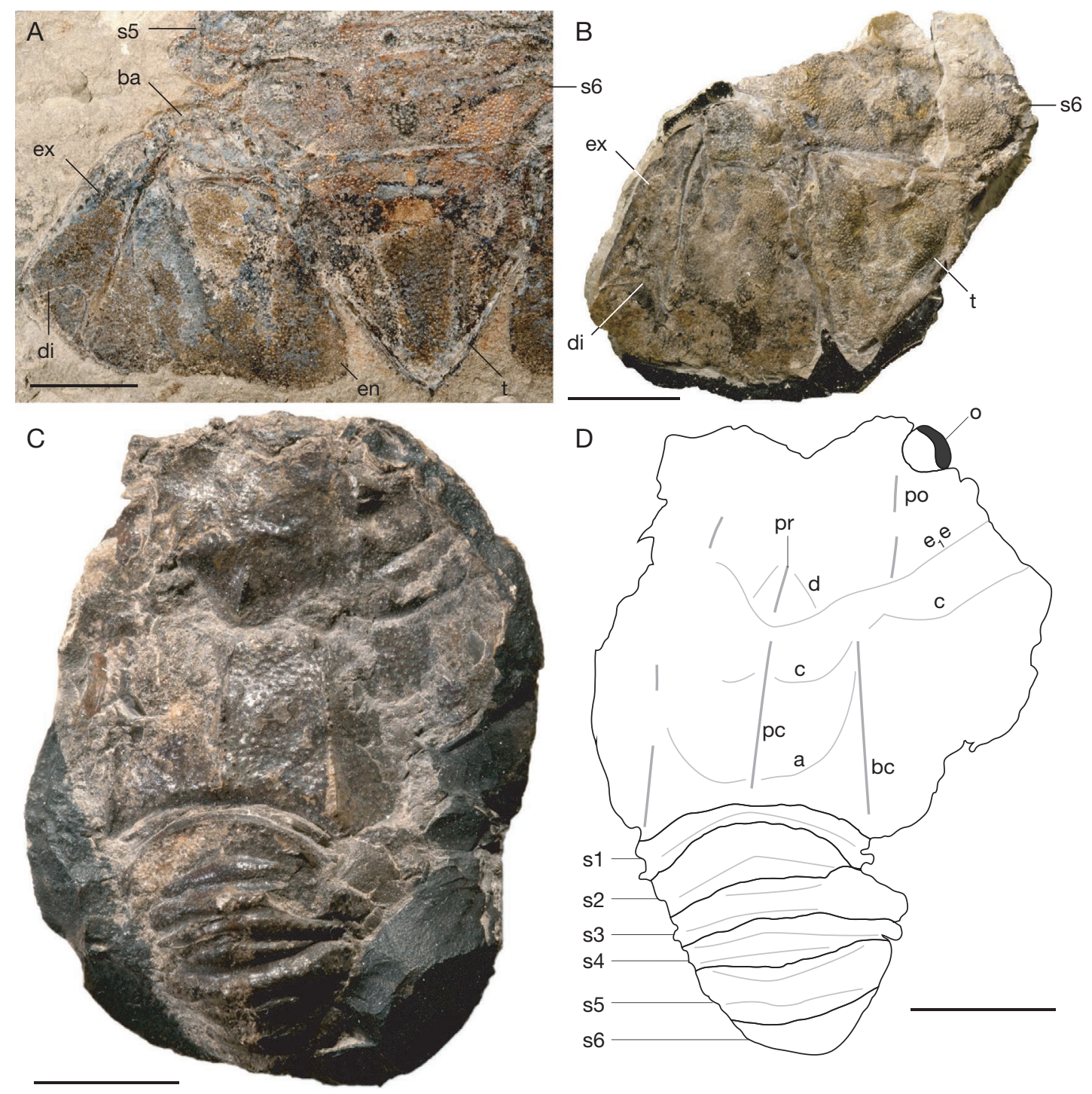

FIG. 7. - Proeryon giganteus (Van Straelen, 1923): A, MNHN.F.A50714, cross-polarized light; B, paratype UJF-ID 11548, cross polarized light; C, D, UJF-ID.14052 cross-polarized light (C) and line-drawing (D); Abbreviations: a, branchiocardiac groove; ba, uropodal basipod; bc, branchial carina; c, postcervical groove; d, gastro-orbital groove; di, diaeresis; $\mathbf{e}_{1} \mathbf{e}$, cervical groove; en, uropodal endopod; ex, uropodal exopod; o, eye; pc, postcervical carina; po, postorbital carina; pr, postrostral carina; s1-s6, pleonites 1-6; t, telson. Scale bars: A, B, $20 \mathrm{~mm}$; C, D, $10 \mathrm{~mm}$. Illustrations: D. Audo (MNHN).

\section{ONTOGENY}

Three small specimens (MNHN.F.A50710, A50727, A50730, carapace length $c .9 \mathrm{~mm}$ ) possibly represent juveniles of $P$. giganteus based upon their large eyes in hemicircular ocular incision. The presence of a diaer- esis on the uropodal exopod of MNHN.F.A50727 reinforces this hypothesis. Small specimens differ from larger ones by a slightly narrower carapace, and a narrower pleon. Two larger specimens (MNHN.F.A50720 and FSL 170521) are far more similar to the adults. 


\section{Genus Willemoesiocaris Van Straelen, 1925}

Willemoesiocaris Van Straelen, 1925: 128-130, fig. 65, pl. 3, fig. 2. — Roman 1928: 109, fig. 17. - Glaessner 1929: 398; 1969: R471.

Paleopentacheles - Van Straelen 1923: 88, fig. 5.

Eryon (Palaeopentacheles) - Balss 1924: 175.

Etymology. - Dedicated by Van Straelen (1925) to Rudolf von Willemoes-Suhm (1847-1875), a German naturalist who first proposed affinities between extant Polychelidae and fossil Eryonidae.

TYPE SPECIES. - Willemoesiocaris ovalis Van Straelen, 1923, by monotypy.

INCLUDED SPECIES. - Only the type species is known.

DiAGNOSIS. - As for type species (monospecific genus),

\section{REMARKS}

Willemoesiocaris was erected by Van Straelen (1925) to accommodate Palaeopentacheles ovalis. Willemoesiocaris differs from Palaeopentacheles Knebel, 1907 by: wider ocular incision (smaller and enclosed laterally by a spine in Palaeopentacheles); marked cervical and postcervical incisions (not marked in Palaeopentacheles); cervical and postcervical grooves marked across carapace (very shallow laterally in Palaeopentacheles); posterior transverse groove on pleonal terga cutting axial carina (axial carina cutting posterior transverse groove in Palaeopentacheles); subcircular scaphocerite (fusiform in Palaeopentacheles).

In fact, our examination of all fossil genera of polychelidan lobsters shows that Willemoesiocaris probably has close affinities with Palaeopolycheles Knebel, 1907, which is characterized as follows: ovoid carapace outline in dorsal view; straight branchial carina; posterior transverse grooves on pleonal terga cutting axial carina; subcircular scaphocerite; P1 merus with very rounded margins. Willemoesiocaris still differs from Palaeopolycheles in having its postcervical groove being oblique between branchial carina and median line (curving forward, as in most other eryonoids in Palaeopolycheles).

Schweigert \& Dietl (1999) considered Palaeopolycheles as synonymous with Coleia. However, Palaeopolycheles can be shown to be different from
Coleia based upon the following characters: shallower frontal margin (deep in Coleia); straight branchial margin (curving inward in the region of cervical and postcervical grooves in Coleia); posterior transverse grooves on pleonal terga cutting axial carina (cut by axial carina in Coleia); subcircular scaphocerite (fusiform in Coleia); P1 merus with rounded margins (straight in Coleia); narrower P1 carpus (as wide as propodus in Coleia); P1 propodus narrower near the insertion of dactylus (straight margins in Coleia). For all these reasons, we consider Willemoesiocaris and Palaeopolycheles as valid and distinct from Coleia. Finally, we temporarily ascribe Willemoesiocaris and Palaeopolycheles to Coleiidae, based upon their diaeresis on uropodal exopod, their sharp anterolateral angle, their well-developed projected from ocular incision and their wide Mx3 ischium. However, Willemoesiocaris also possesses a rounded, almost saddle-shaped s2 tergopleuron, character mostly known in Polychelidae. This character is a synapomorphy of Pleocyemata (Burkenroad 1963), and therefore a symplesiomorphy of polychelidans. For this reason, the presence of a rounded, almost saddle shaped s2 tergopleuron does not preclude an ascription to Coleiidae. As for Proeryon, only a phylogenetic analysis will be able to confirm or infirm this ascription.

Willemoesiocaris ovalis (Van Straelen, 1923) (Figs 2G, H; 8)

Palaopentacheles ovalis Van Straelen, 1923: 88, fig. 5.

Eryon (Palaeopentacheles) ovalis - Balss 1924: 175.

Willemoesiocaris ovalis - Van Straelen 1925: 128-130, fig. 65, pl. 3, fig. 2. — Roman 1928: 109, fig. 17. — Glaessner 1929: 398; 1969: R471. —Charbonnier 2009: 158159, 163, fig. 246, non fig. 404. - Schweitzer et al. 2010: 45. - Charbonnier et al. 2010: 115-117, fig. 4h.

Coleia sp. 3 - Charbonnier 2009: 159, 226, fig. 397.

"Indeterminate polychelid crustacean" - Charbonnier 2009: 228, 229, fig. 405.

Etymology. - Not indicated in original description, probably alluding to the oval outline of carapace. 
TYPE MATERIAL. — Holotype: UJF-ID.11542 (Fig. 7AB) by monotypy.

TyPe LOCAlity. - Ravin des Mines, near La Boissine, La Voulte-sur-Rhône Lagerstätte, Ardèche, RhôneAlpes, France.

Type AGE. - Early Callovian, Gracilis ammonite Zone.

ADDITIONAL SPECIMENS. - FSL 170602, 710082 . MNHN.F.A29521, A50723 (Fig. 8D), A50734, A50737, A50738, A50739. - PIMUZ.23043 (Fig. 8C). — UJFID. 14028 .

DiAGNOSIS. - Dorsoventrally flattened carapace with an ovoid outline in dorsal view; very large ocular incision; subtriangular mediolateral margin, rounded posteriorly; postrostral and postcervical carinae absent; postcervical groove deep from postcervical incision to branchial carina, strongly curving backward near median line; very large eye projected from ocular incision; antenna with a pyriform scaphocerite; very thin and elongate pereiopods.

\section{DESCRIPTION}

\section{Carapace outline}

Dorsoventrally flattened carapace with ovoid outline in dorsal view; concave frontal margin, poorly preserved; anterolateral angle forming a large spine; lateral margin incised by ocular, cervical and postcervical incisions; very large and hemicircular ocular incision opening laterally; anterolateral margin rounded posteriorly, subparallel to longitudinal axis; anterolateral cervical spine absent; large triangular cervical incision; sharp subtriangular mediolateral margin, slightly rounded posteriorly, shorter than anterolateral margin; triangular postcervical incision, smaller than cervical incision; posterolateral margin rounded anteriorly, straight posteriorly; rounded posterolateral angle confluent with pleon; slightly concave posterior margin strengthened by a posterior carina.

\section{Carapace carinae and grooves}

Postrostral and postcervical carinae absent, median line only marked by a very shallow groove; postorbital and branchial carinae merged, forming a raised carina extending from ocular incision cut by cervical and postcervical grooves then straight and reaching posterolateral angle; submarginal carina not preserved anteriorly, parallel to lateral margin, reaching posterolateral angle; deep and slightly oblique cervical groove extending from cervical incision, slightly curving backward before cutting median line at half carapace length; deep postcervical groove, transverse from postcervical incision to branchial carina, strongly curving backward near median line, reaching median line without cutting it at two thirds of the length of carapace; branchiocardiac groove extending from postcervical groove, on the inner side of branchial carina, extending backward obliquely toward median line; short gastro-orbital groove, extending obliquely from cervical groove toward postrostral carinae.

\section{Pleon}

Pleon about as wide and as long as carapace; badly preserved s1 tergum, shorter than the others; subrectangular s2-s5 terga with two deep transverse grooves delimiting three transverse regions: smooth, crescent-shaped region, tuberculate region with a faint median carina, and tuberculate, crescentshaped region; subtrapezoidal s6 tergum, badly preserved; short subtriangular s1 tergopleuron, poorly preserved; rounded, almost saddle-shaped s2 tergopleuron with a spine curved forward on lateral margin; subtriangular s3-s5 tergopleura with a spine curved forward on lateral margin, poorly preserved; subtriangular telson shorter than uropods, poorly preserved.

\section{Eyes and cephalic appendages}

Very large eye carried on a short peduncle; poorly preserved antennula with bulbous basipodite carrying long flagellum (exopodite) endopodite not preserved; antenna formed of long and slightly curved basipodite inserted near ocular peduncle, carrying: 1) pyriform scaphocerite (exopodite) strengthened by longitudinal median carina; and 2) endopodite consisting of two subrectangular podomeres carrying thin flagellum of unassessable length (probably short); mandibles with subtriangular apodeme, incisor process forming teeth of uneven size (one bigger than the others) and short poorly preserved palp (consisting at least of two podomeres) articulated anteriorly at the boundary between apodeme and incisor process. 


\section{Thoracic appendages}

$\mathrm{Mx} 3$ with large subtriangular ischium carrying four subrectangular podomeres decreasing in size distally; extremely elongate, slender, chelate P1, with ischium cut by autotomy zone, elongate and thin merus with bulbous anterior portion, elongated, thin carpus, propodus forming a long palm and a long pollex, long and thin dactylus; chelate, very thin and elongate P2-P4.

\section{Pleonal appendages}

Uropods with ovoid endopod strengthened by raised median carina and petaloid exopod strengthened by raised median carina and faint lateral carina along its lateral margin, cut by rounded diaeresis.

\section{Ornamentation}

Carapace and pleon covered by tubercles.

\section{ONTOGENY}

Two small specimens (MNHN.F.A50723, A50734) with a carapace length measuring $c .8 \mathrm{~mm}$ are known. They share the typical shape of adult claws and differ mainly in their larger eyes, narrower pleon and rounder carapace (Fig. 8D).

Family POLYCHELIDAE Wood-Mason, 1874

Type Genus. — Polycheles Heller, 1862.

InCluded eXtant genera. - Cardus Galil, 2000, Homeryon Galil, 2000, Polycheles, Pentacheles SpenceBate, 1878, Stereomastis Spence-Bate, 1888, Willemoesia Grote, 1873.

InCLUDED EXTINCT GENERA. - Hellerocaris Van Straelen, 1925; Antarcticheles Aguirre-Urreta, Buatois, Chernoglasov \& Medina, 1990.

\section{REMARKS}

Polychelidae is the only family of extant polychelidan lobsters including only blind species, with their cornea and sometimes even the ocular peduncle reduced (Galil 2000). Four fossil genera have been ascribed to Polychelidae (Glaessner 1969): Antarcticheles Aguirre-Urreta, Buatois, Chernoglasov \& Medina, 1990, Pal- aeopolycheles Knebel, 1907, Palaeopentacheles Knebel, 1907, and Willemoesiocaris Van Straelen, 1925. Willemoesiocaris and Palaeopolycheles are herein provisionally assigned to Coleiidae. Palaeopentacheles is currently ascribed to its own family Palaeopentachelidae by Ahyong (2009). Antarcticheles is included in Polychelidae by Aguirre-Urreta et al. (1990) based upon the shape of carapace, distinct cervical and postcervical grooves and median carina. Examination of high resolution pictures of the holotype of Antarcticheles antarcticus Aguirre-Urreta, Buatois, Chernoglasov \& Medina, 1990 reveals large rounded ocular incisions that probably housed well-developed eyes. Direct comparison with the V-shaped to slit-like or reduced ocular incisions in extant polychelid species, suggests that Antarcticheles is not a true member of Polychelidae but more probably a member of the stem-group of Polychelidae. In conclusion, we consider that Polychelidae do not include fossil representatives and that the family should be restricted to species sharing the principal synapomorphy distinguishing polychelids from all fossil polychelidans: the reduction of the eyes. It could be noted that this synapomorphy is only, of course, only relevant within polychelidans: blind species also occurs in other clades of reptantians (for instance Acanthacaris Spence-Bate, 1888, Thymops Holthuis, 1974 and Thymopsis Holthuis, 1974; - see Holthuis 1974).

\section{Genus Hellerocaris Van Straelen, 1925}

Hellerocaris Van Straelen, 1925: 154. — Glaessner 1929: 207; 1969: R470.

Palaeopolycheles - Van Straelen 1923: 89 [pro parte].

Etymology. - Dedicated by Van Straelen (1925) to Camill Heller (1823-1917), an Austrian zoologist who described the first extant polychelidan lobster.

TYPe SPECIES. - Palaeopolycheles falloti Van Straelen, 1923 , by monotypy.

INCLUDED SPECIES. - Only the type species is known.

DiagNOSIs. - As for type species (monospecific genus). 

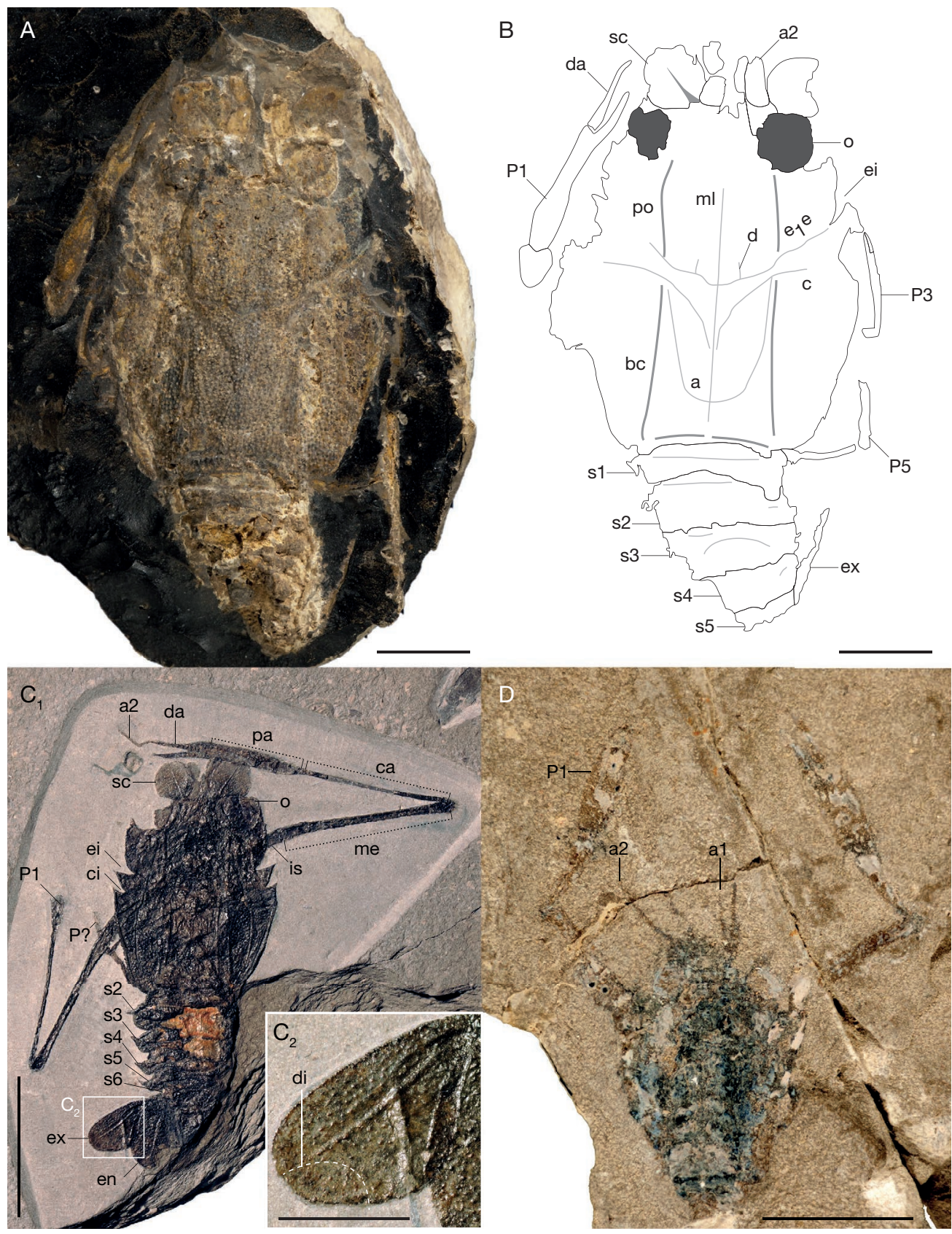

FIG. 8. - Willemoesiocaris ovalis (Van Straelen, 1923): A, B, holotype UJF-ID.11542, cross-polarized light (A) and line drawing (B); C, PIMUZ.26673 showing long and slender pairs of claws; D, MNHN.F.A50723; abbreviations: a, branchiocardiac groove; a2, antenna; bc, branchial carina; c, postcervical groove; ca, carpus; ci, postcervical incision; d, gastro-orbital groove; da, dactylus; $\mathbf{e}_{1} \mathbf{e}$, cervical groove; ei, cervical incision; en, uropodal endopod; ex, uropodal exopod; is, ischium; $\mathbf{m l}$, median line; o, eye; P1-P5, pereiopods 1 to 5; P?, indeterminate pereiopod; pa, palm; po, postorbital carina; s1-s5, pleonites 1 to 5; sc, scaphocerite. Scale bars: A, B, 10 mm; C, 20 mm; D, 5 mm. Illustrations: A, B, D, D. Audo (MNHN); C, H. Furrer (PIMUZ). 


\section{REMARKS}

Hellerocaris falloti was initially ascribed to Palaeopolycheles by Van Straelen (1923). Later, Van Straelen (1925) erected a new genus to accommodate this species but without justification. Directly comparison based upon the type specimens reveals that Hellerocaris differs from Palaeopolycheles based upon its subrectangular carapace (ovoid in Palaeopolycheles), its smaller ocular incisions, its shallow cervical and postcervical incisions (deeper in Palaeopolycheles), its axial carina on pleonal terga cutting posterior transverse groove (cut by posterior transverse groove in Palaeopolycheles), its fusiform scaphocerite (subcircular in Palaeopolycheles), and its small diaeresis cutting the distal extremity of uropodal exopod (wider in Palaeopolycheles).

Hellerocaris was one of the two genera initially ascribed to Coleiidae by Van Straelen, (1925) based upon the presence of a diaeresis on uropodal exopod, ocular incisions and a scaphocerite. This position was followed by all successive authors. Examination of the type material of $H$. falloti and of new specimens leads us to a different conclusion. Indeed, the cervical and postcervical incisions in Hellerocaris are very small (Figs 2J; 9A, C, D, $\mathrm{G}$; large in Coleia), the $\mathrm{Mx} 3$ ischium is slender (widened in Coleia, Proeryon), the s2 tergopleuron is saddle-shaped (triangular in all coleiids) and overlaps the $s 1$ tergopleuron (no overlap in all coleiids). Thus, we consider Hellerocaris to be not a true member of Coleiidae. Instead, we assume that Hellerocaris exhibits more affinities with the Polychelidae (e. g. narrow carapace, shallow cervical and postcervical incisions, axial carina cutting transverse groove on s2-s5, s2 tergopleura overlapping $s 1$ tergopleura) but without sharing all the diagnostic characters of the Polychelidae such as the reduced eyes and the eryoneicus larvae: Indeed, the occurrence of very small specimens (Fig. 9G) is probably incompatible with that of giant eryoneicus larvae which are usually far larger than these specimens. Moreover, Hellerocaris shows well-developed eyes and adult-like juveniles. For these reasons, as for Antarcticheles, we consider Hellerocaris to be a member of the stem-group of Polychelidae.

\section{Hellerocaris falloti (Van Straelen, 1923)}

(Figs 2J-L; 9)

\section{Palaeopolycheles falloti Van Straelen, 1923: 89.}

Hellerocaris falloti - Van Straelen 1925: 154-156, fig. 68, pl. 6, figs 1-2. — Roman 1928: 109-110, fig. 19. — Glaessner 1929: 207; 1969: R468, fig. 273.1, R470. — Kuhn 1952: 160, fig. 2. — Levitski 1974: 111. — Fischer 2003: 241. - Charbonnier 2009: 158-159, 163, figs 243, 224, 226, 398. - Schweitzer et al. 2010: 44. - Charbonnier et al. 2010: 115-117, 125, fig. 4G.

"Indeterminate coleiid crustacean" - Charbonnier 2009: 227, fig. 402.

Etymology. - Dedicated by Van Straelen (1923) to Paul Fallot (1889-1960), then senior lecturer in geology at the University of Grenoble.

Type MATerial. — Lectotype: UJF-ID.11553-11903 (Fig. 9A), part and counterpart, coll. Gevrey, designated by Van Straelen (1925). Two paralectotypes (UJF-ID. 11551 [Fig. 9B, F], 11896, coll. Gevrey).

Type Locality. - Ravin des Mines, near La Boissine, La Voulte-sur-Rhône Lagerstätte, Ardèche, RhôneAlpes, France.

TYPe AGE. - Early Callovian, Gracilis ammonite Zone.

Additional SPECimens. — FSL 170601 (coll. Caillet), FSL 710108 (coll. Charbonnier). — MNHN.F.A29510, A29520, A47495 (Fig. 9C, D), A48872, A48873, A50709 (Fig. 9G), A50711, A50721, A50722, A50732, A50733, R07060 (Fig. 9E). — UJF-ID.14024.

DiagNosis. - Dorsoventrally flattened carapace with subrectangular outline in dorsal view; very small cervical and postcervical incisions; small eyes slightly projected from ocular incision; saddle-shaped s 2 tergopleuron; small diaeresis cutting the tip of uropodal exopod.

\section{DESCRIPTION}

\section{Carapace outline}

Dorsoventrally flattened carapace with subrectangular outline in dorsal view; wide and slightly concave frontal margin; anterolateral angle forming sharp triangular angle; lateral margin incised by ocular, cervical and postcervical incisions; subcircular ocular incision; poorly preserved anterolateral margin, slightly rounded, subparallel to longitudinal axis; anterolateral cervical spine absent; very small cervical incision; poorly preserved mediolateral margin, straight, shorter than anterolateral margin; very 


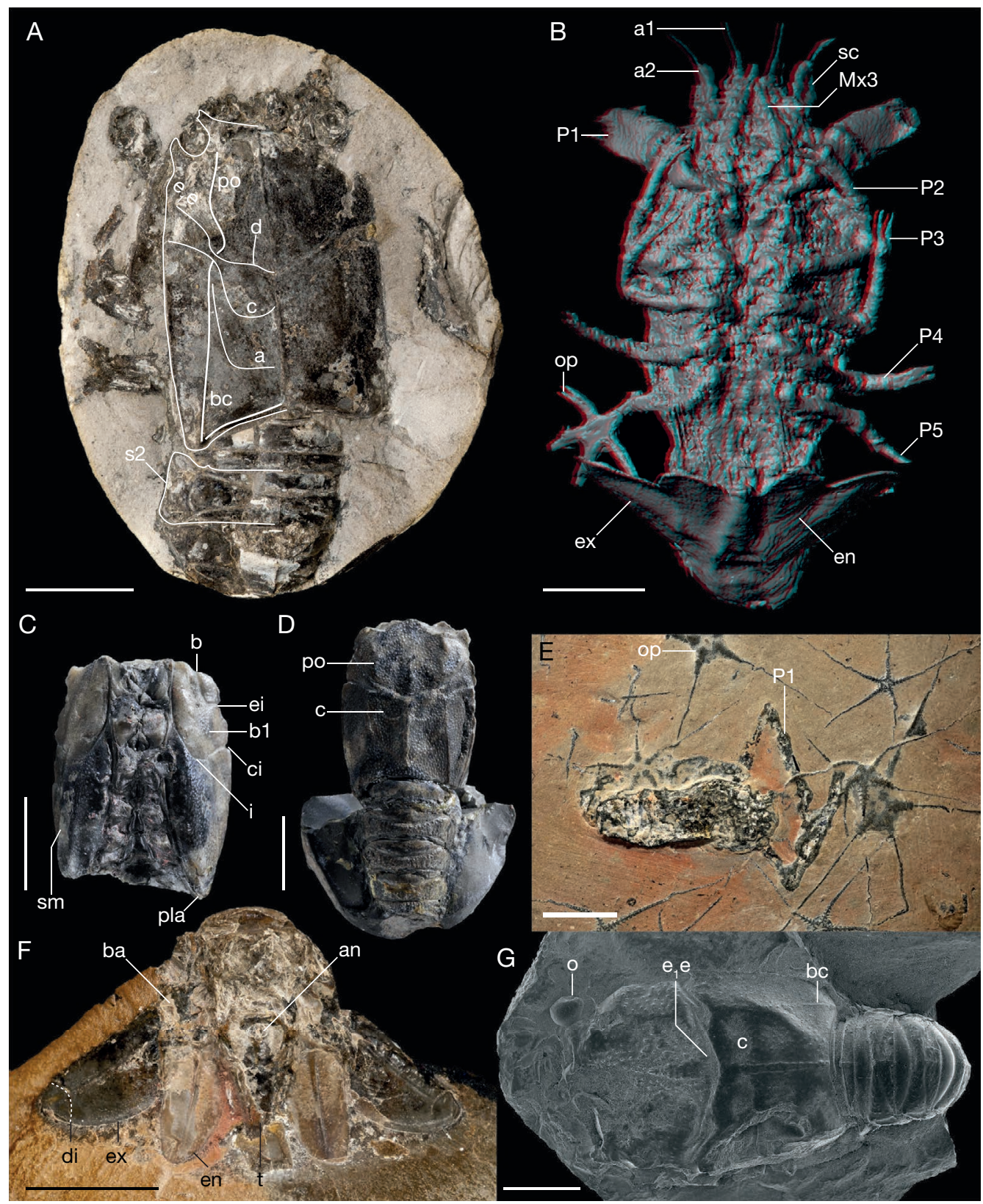

FIG. 9. - Hellerocaris falloti (Van Straelen, 1923): A, lectotype UJF-ID.11553, cross-polarized light; B, paralectotype UJF-ID.11551a, redcyan anaglyph of model reconstructed from CT-scan radiographies (red-cyan stereo glasses recommended); C, D, MNHN.F.A47495, ventral view of cephalothorax (A) and dorsal view of whole specimen (B); E, specimen MNHN.F.R07060 partly coated by pyrite, dorsal view, note the shape of first pereiopods; F, paralectotype, UJF-ID.11551a, cross-polarized light; G, MNHN.F.A50709, SEM picture; abbreviations: a, branchiocardiac groove; a1, antennula; a2, antenna; an, anus; b, antennal groove; b1, hepatic groove; bc, branchial carina; ba, basipodite; c, postcervical groove; ci, postcervical incision; d, gastro-orbital groove; di, diaeresis; $\mathbf{e}_{\mathbf{1}} \mathbf{e}$, cervical groove; ei, cervical incision; en, uropodal endopod; ex, uropodal exopod; i, inferior groove; Mx3, third maxilliped; op, undetermined ophiuroid; P1-P5, pereiopod 1 to 5; pla, posterolateral angle; po, postorbital carina; sc, scaphocerite; sm, submarginal carina; t, telson. Scale bars: A-D, F-G, 10 mm; E, 2 mm. Illustrations: A, E, F, D. Audo (MNHN); B, F. Goussard (MNHN) and D. Audo (MNHN); C, D, G, P. Loubry (MNHN). 

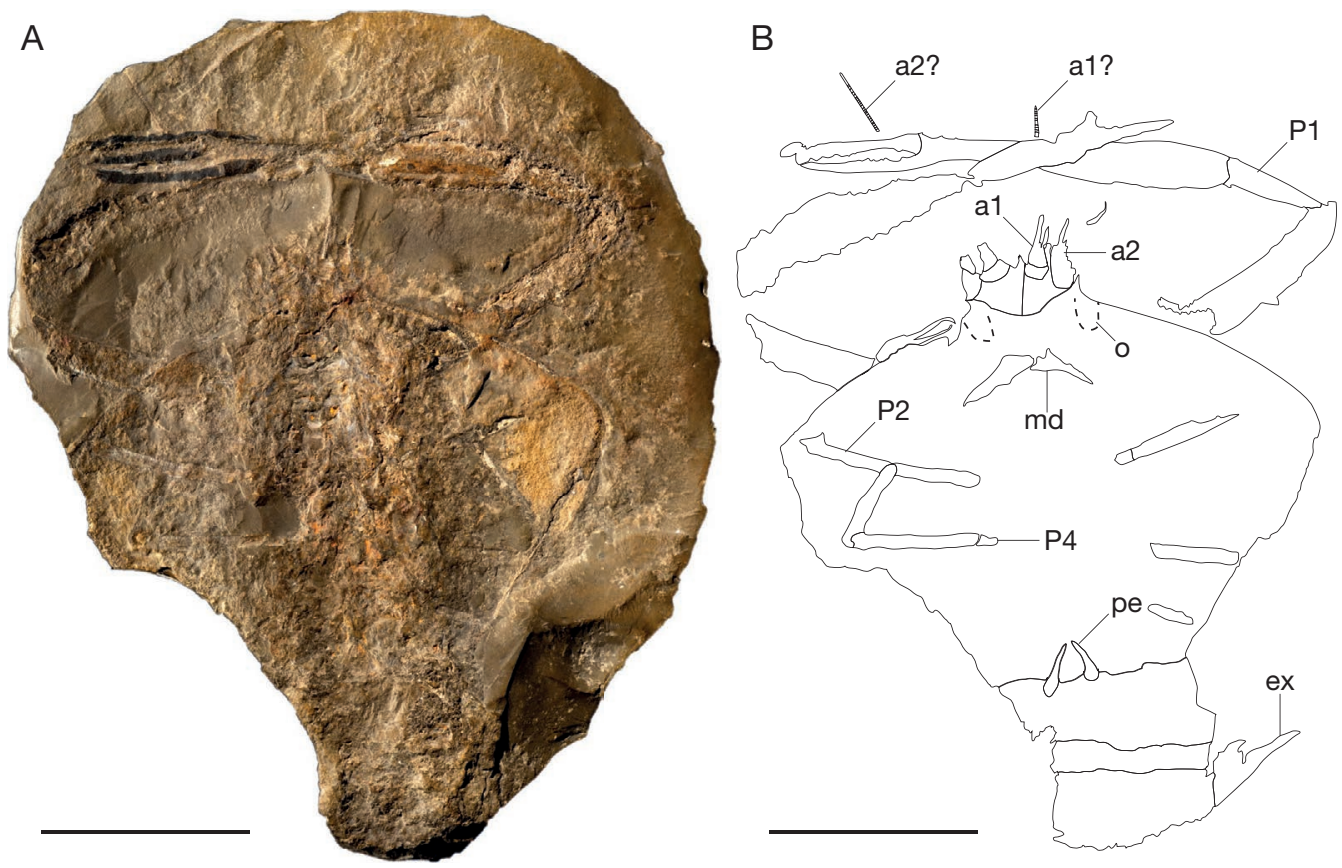

FIG. 10. - Adamanteryon fourneti n. gen., n. sp.: A, B, holotype UJF-ID.11541, cross-polarized light (A) and line drawing (B). Abbreviations: a1, antennula; a2, antenna; ex, uropodal exopod; md, mandible; o, ocular incision; P2-P4, pereiopod 2 to 4; pe, petasma. Scale bars, $5 \mathrm{~cm}$. Illustrations: D. Audo (MNHN).

small postcervical incision; posterolateral margin slightly rounded anteriorly, straight posteriorly, with short, rounded spines; angular posterolateral angle, confluent with pleon; slightly concave carinate posterior margin.

\section{Carapace carinae and grooves}

Postrostral and postcervical carinae separated by cervical groove; postrostral carina raised in the second half of cephalic region; raised postcervical carina; postorbital and branchial carinae merged, forming a raised carina extending from ocular incision cut by cervical groove then parallel to median line and reaching posterolateral angle; thin submarginal carina stretching from ventral margin anteriorly near Mx3 insertion, parallel to lateral margin, reaching posterolateral angle; deep and slightly oblique cervical groove extending from cervical incision, slightly curving backward before cutting median line at half the carapace length; postcervical groove very deep from postcervical incision to branchial margin, effaced near branchial margin, curving backward then forward between branchial carina and postcervical carina; faint branchiocardiac groove extending obliquely from postcervical groove near branchial carina to posterior portion of postcervical carina; short gastro-orbital groove extending longitudinally from cervical groove where it bends posteriorly (between branchial and postrostral carinae); deep inferior groove (on ventral side) connected to postcervical groove through postcervical incision, cutting pterygostomian flap transversally, cut by submarginal carina; shallow hepatic groove (on ventral side) extending longitudinally from the antennal groove to inferior groove; deep antennal groove extending longitudinally from ocular incision, curving outward to merge with cervical groove through cervical incision.

\section{Pleon}

Pleon longer than carapace and about as wide as carapace; smooth s1 tergum shorter than s2-s6; 
subrectangular s2-s5 terga with two deep transverse grooves delimiting three transverse regions: smooth-crescent-shaped region, tuberculate region with faint median carina and tuberculate, thin crescent-shaped region; subtrapezoidal s6 tergum, poorly preserved; saddle-shaped s2 tergopleuron covering s1 tergopleuron; lanceolate s3-s6 tergopleura, strengthened by transverse carina; triangular telson strengthened by straight median carina and curved lateral carina, anus preserved at the anterior end of telson.

\section{Eyes and cephalic appendages}

Small eye slightly projected from ocular incision; poorly preserved antennula, consisting of wide basipodite carrying two flagella, inner one (endopodite) being thicker than the outer (exopodite); poorly preserved antenna, endopodite composed of three subcylindrical podomeres carrying a flagellum of unassessable length, narrow, fusiform scaphocerite (exopodite), with a sharp tip; mandibles with a long subtriangular apodeme carrying incisor process forming sharp teeth of uneven size.

\section{Thoracic appendages}

Elongate Mx3 inserted very close to $\mathrm{P} 1$, with slender ischium and merus, stocky carpus, propodus and small dactylus; large, chelate P1; slender P1 ischium cut by an autotomy zone, and slightly too short to reach the carapace margin; P1 merus slightly longer than ischium and widening distally, short subtriangular P1 carpus; elongate $\mathrm{P} 1$ propodus, about three times as long as carpus; slender P1 dactylus about one third of the length of propodus; chelate P2-P4, smaller than $\mathrm{P} 1$, composed of subcylindrical podomeres of similar width; P5 slightly shorter than P2-P4, distal extremity too poorly preserved to check presence of a claw.

\section{Pleonal appendages}

Pleopods poorly preserved; uropods with: subquadrate basipodite; long uropoal exopod with a small diaeresis at the distal extremity, a straight outer margin, a curved inner margin fringed by dense setae, a pair of shallow longitudinal grooves surrounding a slightly vaulted area; lanceolate uropodal endopod, fringed by setae on its inner margin and strengthened by a raised carina surrounded by shallow grooves.

\section{Ornamentation}

Carapace and pleon covered by small tubercles.

\section{ONTOGENY}

Six specimens (MNHN.F.A29520, A48872, A48873, A50709, A50732, A50733) have a carapace length ranging from $c .4$ to $7 \mathrm{~mm}$ (e.g., Fig. 9G). They are far smaller than other specimens whose carapace lengths measure c. $21 \mathrm{~mm}$. These specimens slightly differ from larger specimens by slightly more convex lateral margin and proportionally larger eyes. We interpret these specimens as juveniles of $H$. falloti.

\section{Family uncertain}

\section{Genus Adamanteryon n. gen.}

Etymology. - Combination of the Latin adamas, adamantis (= diamond), alluding to the shape of the outline of carapace, reminiscent of the outline of a traditional diamond cut. The gender of the genus is masculine.

TYPE SPECIES. - Adamanteryon fourneti n. sp.

INCLUDED SPECIES. - Only the type species is known.

Diagnosis. - Monospecific genus, as for type species.

\section{REMARKS}

Adamanteryon n. gen. clearly differs from all other polychelidan lobsters by its unique diamond-shaped carapace outline. Its familial assignment is however uncertain due to the poor preservation of the single available specimen of this monospecific genus. The length of antennules and antennae, and the posterolateral angle of carapace apparently closely associated with pleon point toward an assignment to Coleiidae. Alternatively, the wide carapace corresponds more closely to the Eryonidae habitus. Additional, more well-preserved samples will therefore be required to shed light on the familial affinities of this unusual genus. 


\section{Adamanteryon fourneti $\mathrm{n}$. sp.}

(Figs 2I; 10)

Coleia gigantea - Wilby 2002: 349, fig. 3.4.7.1.

Coleia sp. 2 - Charbonnier 2009: 159, 226, fig. 396. Charbonnier et al. 2010: 115, 117.

Type MATERIAL. - Holotype: UJF-ID.11541 (Fig. 10).

Eтyмology. - In honour to Joseph Fournet (18011869), first professor of the University of Lyon and one of the first to study scientifically the La Voulte outcrop, he dated the outcrop into which will become the Callovian and mentioned the occurrence of ophiuroids in marly beds.

Type LOCALity. - Ravin des Mines, near La Boissine, La Voulte-sur-Rhône Lagerstätte, Ardèche, RhôneAlpes, France.

TYPE AGE. - Early Callovian, Gracilis ammonite Zone.

DiAGNOSIS. - Dorsoventrally flattened carapace with a diamond-shaped outline in dorsal view; cervical and postcervical incisions very small or absent; antennular and antennal flagella very long.

\section{DESCRIPTION}

\section{Carapace outline}

Dorsoventrally flattened carapace with a diamondshaped outline in dorsal view; concave frontal margin, narrow compared to width of carapace; anterolateral angle forming a large spine; ocular incision poorly preserved; cervical and postcervical incisions absent or very small; angular posterolateral angle, not associated with pleon; wide and concave posterior margin, poorly preserved.

\section{Pleon}

Poorly preserved pleon, less than half the width of carapace and probably about as long as carapace.

\section{Eyes and cephalic appendages}

Antennula composed of a wide basipodite carrying a long and slender outer flagellum (exopodite) and an endopodite consisting of at least two enlarged podomeres carrying a long flagellum of unassessable length; antenna with a very long and thin flagellum, probably longer than carapace, scaphocerite not preserved.

\section{Thoracic appendages}

Chelate, large and elongate P1; distally curved P1 dactylus; straight P1 pollex - both about as long as one fourth of propodus; slender P1 propodus, narrower near insertion of dactyle, about as long as carapace; stout subtriangular P1 carpus; P1 merus about twice as long as carpus; short P1 ischium; two others slender chelate pereiopods preserved, about twice smaller as P1, probably corresponding to $\mathrm{P} 2$ and $\mathrm{P} 3$.

\section{Pleonal appendages}

Poorly preserved petasma; long uropodal exopod poorly preserved, slightly shorter than pleon.

\section{DISCUSSION}

\section{HIGH DIVERSITY OF POLYCHELIDAN LOBSTERS}

The fossil record of polychelidan lobster is almost entirely documented by specimens from Lagerstätten. As a result, the record is rather discontinuous and study of variations in palaeobiodiversity would be strongly biased by the relative abundance of Lagerstätten. For instance, the occurrence of very extensive "Solnhofen-type" Lagerstätten in the Late Jurassic of Europe leads to a high known palaeobiodiversity in this period. In the Middle Jurassic, only two Lagerstätten have yielded polychelidan lobsters: Monte Fallano (one species, Bravi et al. 2014) and La Voulte (seven species, present study). For this reason, the La Voulte Lagerstätte fills an important gap in the fossil record of polychelidan lobsters.

This high diversity of La Voulte polychelidans is evident when compared to other Lagerstätten (Fig. 11). Comparison of specific, generic, and familial diversity of eight Jurassic Lagerstätten yielding multiple species of polychelidan lobsters highlights that the La Voulte Lagerstätte is the second outcrop in term of specific diversity and the first in term of generic and familial diversity. Surprisingly, the very small La Voulte outcrop (about $200 \mathrm{~m}^{2}$ ) can be compared in term of palaeobiodiversity to well-known, extensively quarried Lagerstätten such as Lyme Regis or Eichstätt basin. 
One of the most striking differences between La Voulte and other Lagerstätten is that each species at La Voulte belongs to a separate genus: there is great phylogenetic diversity in addition to specific diversity. This contrasts with 1) the Osteno Lagerstätte where all species are ascribed to Coleia (Pinna 1968, 1969, Teruzzi 1990); 2) the Eichstätt Lagerstätte where three species of Cycleryon and two of Knebelia are described (Frickinger 1994, 1999, Audo et al. 2014b); and 3) the Holzmaden Lagerstätte where four species or five are ascribed to Proeryon (Beurlen 1928, 1930, 1944; Hauff \& Hauff 1981). A more comparable situation is found in Nusplingen, where the generic diversity is almost equal to the specific diversity (Dietl \& Schweigert 2001, 2004, 2011; Schweigert 1997; Schweigert et al. 2012). However, Nusplingen has not yielded yet as many species as La Voulte.

The origin of La Voulte polychelidan high palaeobiodiversity remains to be understood. However, it suggests that either polychelidans are primarily deep-sea crustaceans, or that rather early in their evolution, at least three polychelidan lobster families (Eryonidae, Coleiidae, "stem-Polychelidae") had already colonized deep-water palaeoenvironments.

\section{ORIGIN OF POLYCHELIDAE}

Extant polychelids inhabit deep-water environments (Galil 2000). It could be expected that their closest fossil relatives may also have lived in rather deep environment, such as La Voulte. The reinvestigation of Hellerocaris suggests it might be a close relative of Polychelidae. In addition to the developed eye (and supposed absence of eryoneicus larva), Hellerocaris also differs from Polychelidae by a small diaeresis at the distal extremity of uropodal exopod. This diaeresis is very small compared to that of other polychelidan lobsters. This observation suggests that the loss of the diaeresis in Polychelidae may have occurred by a gradual displacement toward the distal extremity of the diaeresis until it was finally lost. This scenario is also compatible with the stratigraphic record: the earliest polychelidan species (Triassic), Tetrachela raiblana Bronn, 1858, possesses a large diaeresis; $H$. falloti indeed is dated into the Middle Jurassic; earliest species of polychelidan, Tetrachela raiblana Bronn, 1858, possesses a large diaeresis; and polychelids are extant.
Extant polychelids develop indirectly through an eryoneicus larva. This larva is of large size and characterized by an inflated, balloon-like carapace ornamented by abundant spines and possesses reduction of eyes, as in extant adult polychelids (Bernard 1953; Martin 2014). The fossil record of polychelidan lobsters is mainly known from specimens of large size, and rare juveniles similar to the adults (Bravi et al. 2014; Audo et al. 2014b). The only known true larvae of polychelidan lobster have been identified but not yet published from the Hadjoula Lagerstätte (Late Cretaceous, Lebanon) and resemble eryoneicus larvae by their large size and spinose carapace and differ from them by their developed eyes and uninflated carapace.

As mentioned in the systematic treatment, $H$. falloti and W. ovalis are probably among close relatives of extant polychelids. Small specimens of both species have been identified in La Voulte (Figs 8D; 9G). Their morphology is similar to that of the adult, as it is also the case for most other polychelidan fossils. In this situation, as noted for Hellerocaris, the occurrence of a small juvenile seems incompatible with an ontogeny including an eryoneicus larva, because they are far smaller than most eryoneicus larvae. Yet, it is possible to imagine the existence a very small eryoneicus larva in the ontogeny of these species. However, such small larva would not be the equivalent of the giant eryoneicus larvae of the extant polychelids, which probably allow dispersion on long distances and a substantial part of the growth to occur among plankton. This absence of giant eryoneicus larvae further justifies the assignment of $H$. falloti to stem-Polychelidae (instead of Polychelidae sensu stricto) and suggests that eryoneicus larvae probably evolved later in the evolutionary history of polychelidan lobsters. Finally, it seems probable that development through eryoneicus larva can be retained as a defining character of Polychelidae.

\section{Palaeoecology}

Extant polychelids are blind and live principally at great depths (up to 6000 meters: Galil 2000). Fossil polychelidan lobsters are more diverse, so far all known species seem to have had developed eyes, and seem to have inhabited more diverse 
palaeoenvironments. Polychelidans from Lyme Regis or Holzmaden probably lived in rather deep palaeoenvironments. Those from "Solnhofen-type" plattenkalks and from Monte Fallano (Bravi et al. 2014) lived in shallower conditions. The La Voulte Lagerstätte preserves perhaps one of the deepest palaeoenvironment yielding fossil polychelidans (Charbonnier et al. 2007a, 2010).

The La Voulte polychelidan community (Fig. 11) is dominated by P. giganteus (c. $48 \%$ of studied sample), the second species in term of abundance is $H$. falloti (c. 22\%) and the third is W. ovalis (c. 13\%). These three species (and also C. romani n. sp.) are probably autochthonous of the depositional environment as all comprise specimens of different sizes suggesting different growth stages preserved in their habitat. Eryonids are less abundant with Eryon ellipticus (c. 7\% of studied samples), followed by C. romani n. sp. (c. 6\%), V. parvulus n. gen., n. sp. (c. 2\%) and $A$. fourneti n. gen., n. sp. (c. 1\%). Due to the absence of juveniles of $E$. ellipticus, this species may be considered as parautochthonous.

The occurrence of $P$. giganteus supports the hypothesis that the La Voulte Lagerstätte preserves a deep sea palaeoenvironment. Indeed, there are several further indications that Proeryon is a deep-sea dwelling genus: 1) eyes in Proeryon are rather large compared to that of most other polychelidans; 2) other species of Proeryon co-occur with large pelagic marine reptiles such as ichthyosaurs and plesiosaurs (e.g., fragments of P. hartmanni (Meyer, 1836), have been discovered in the gut content of an ichthyosaur; Eudes-Deslongchamps 1868); and 3) Proeryon is probably one of the longest living genera of polychelidan lobsters, since it occurs from the Toarcian to the Hauterivian (Schweigert \& Herd 2010), such a longevity may have been favoured by the relative stability of deep-sea palaeoenvironments, less prone to perturbations due to eustatic oscillations.

The diet of extant polychelids is not well known, but at least two feeding habits can be identified: an opportunistic diet such as that Willemoesia forceps (Willemoes-Suhm, 1875), which gut content contains siliceous sponges, fibres of wood, foraminifera, remains of fishes (Firth \& Pequegnat 1971; Gore 1984); and probably a more predatory diet such as Polycheles typhlops Heller, 1862 which feeds on small crustaceans such as euphausiaceans, mysidaceans, amphipods and isopods (Lagardère 1973). Differences in feeding habits are probably linked to the available food. The opportunistic diet of Willemoesia forceps is undoubtedly a result of the scarcity of food in its extremely deep environment (c. 3400-4000 m; Gore 1984). On the other hand, Polycheles typhlops occurs in a shallower environment (600-1300 m; Lagardère 1973) and probably beneficiates from a greater abundance of prey. Cartes \& Sardà (1992) noted that concentration of brittles stars in deep see environments marked eutrophic conditions. La Voulte Lagerstätte, with its extremely abundant brittle star populations and general density of fossil probably correspond to an eutrophic palaeoenvironment sufficiently rich for polychelidans to adopt a predatory diet. In this respect, the long first chelipeds of Proeryon giganteus, Willemoesiocaris ovalis and A. fourneti n. gen., n. sp. were probably well suited to catch small nectobenthic prey.

Willemoesiocaris ovalis is characterized by extensively long and slender first pereiopods, a wide scaphocerite, rather long uropods and large eyes. All these characteristics suggest that Willemoesiocaris was probably nectobenthic (i.e. swimming near the sea-bottom) and was probably able to hunt in the water column.

\section{PERSPECTIVES}

The present study expands our knowledge on the palaeobiodiversity of the La Voulte Lagerstätte, almost doubling the number of polychelidan species and allows to formulate a palaeoecological hypothesis.

A new municipal museum was scheduled to open in La Voulte. This museum could have been able to distribute scientific knowledge on La Voulte and organise a new excavation campaign. Given the concentration of fossils in La Voulte and the exquisite preservation, knowledge of the Jurassic polychelidan lobsters would surely have beneficiated of these new scientific excavations.

However, recent changes in the municipal administration and budget cuts led to the cancelation of this project. 


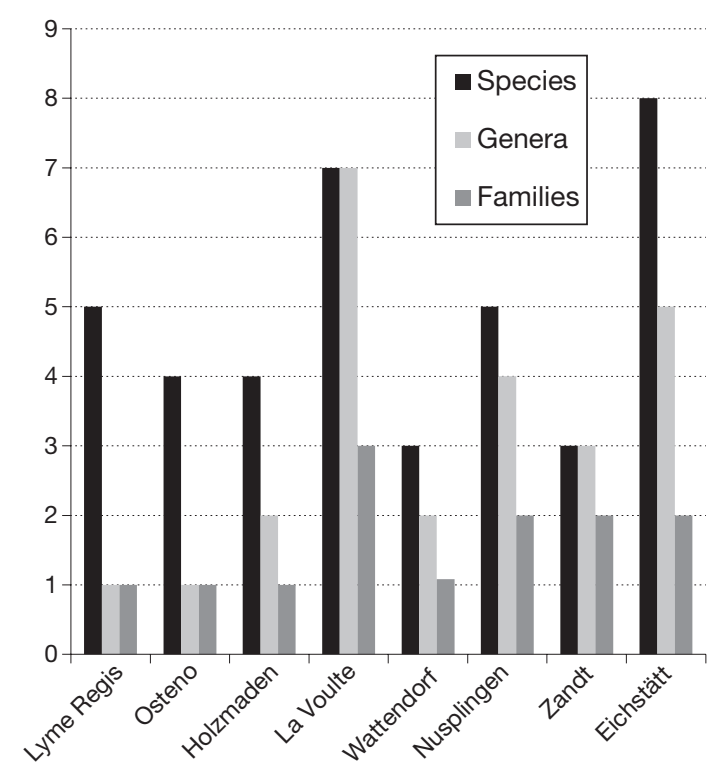

FIG. 11. - Column chart comparing the major Lagerstätten yielding polychelidans in term of specific, generic and family rank diversity.

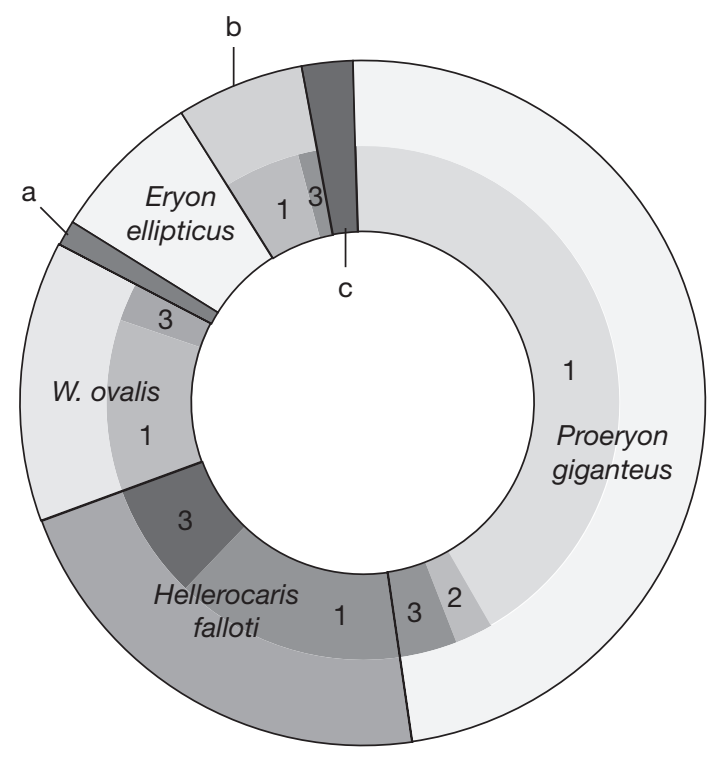

FIG. 12. - Proportion in La Voulte-sur-Rhône polychelidans; outer circle indicates the proportion of each species; inner circle details the proportion of small, intermediate and large specimens. Abbreviations: a, Adamenteryon fourneti n. gen., n. sp.; b, Cycleryon romani n. sp.; c, Voulteryon parvulus n. gen., n. sp.; 1, large "adult" specimen; 2, intermediate specimen; $\mathbf{3}$, small specimen.

uscript. This paper is a contribution to the UMR 7207 CR2P, CNRS-MNHN-UPMC and to the Département Histoire de la Terre (Muséum national d'Histoire naturelle, Paris).

\section{REFERENCES}

Aguirre-Urreta M. B., Buatois L. A., Chernoglasov G. C. B. \& Medina F. A. 1990. — First Polychelidae (Crustacea, Palinura) from the Jurassic of Antarctica. Antarctic Science 2 (2): 157-162.

AHYONG S. T. 2009. - The polychelidan lobster: phylogeny and systematics (Polychelida: Polychelidae), in Martin J. W., Crandall K. A. \& Felder D. L. (eds), Decapod Crustacean Phylogenetics. Taylor \& Francis/CRC Press, Boca Raton: 369-396.

Alessandrello A., Bracchi G. \& Riou B. 2004. — Polychaete, sipunculan and enteropneust worms from the Lower Callovian (Middle Jurassic) of La Voultesur-Rhône (Ardèche, France). Memorie della Società Italiana di Scienze Naturali e del Museo Civico di Storia Naturale di Milano 32 (1): 1-17. 
Audo D., Charbonnier S., Schweigert G. \& Saint MARTIN J.-P. 2014a. - New eryonid crustaceans from the Late Jurassic Lagerstätten of Cerin (France), Canjuers (France), Wattendorf (Germany) and Zandt (Germany). Journal of Systematic Palaeontology 12 (4): 459-479. http://dx.doi.org/10.1080/14772019.201 3.777809

Audo D., Schweigert G., Haug J.T., Haug C., Saint Martin J.-P. \& CharbonNiER S. 2014b. - Diversity and palaeoecology of the enigmatic genus Knebelia (Eucrustacea, Decapoda, Eryonidae) from upper Jurassic Plattenkalks in southern Germany. Palaeontology 57 (2): 397-416. http://dx.doi.org/10.1111/ pala. 12071

BALSS H. 1924. - Studien an fossilen Decapoden II. Palaeontologische Zeitschrift 6 (2): 174-184.

BAYER J. J. 1757. - Monumenta rerum petrificatarum praecipua Oryctographiae Noricae supplementi loco iungenda interprete filio Ferdinando Jacobo Baiero cum tabulis aeneis quindecim. A.R.S., Nuremberg, 20 p., 15 pls.

BERNARD F. 1953. - Decapoda Eryonidae (Eryoneicus et Willemoesia). Dana-report 37, 93 p.

Beurlen K. 1928. — Die Decapoden des Schwäbischen Jura mit Ausnahme der aus den oberjurassischen Plattenkalken stammenden. Beiträge zur Systematik und Stammesgeschichte der Decapoden. Palaeontographica 70: 115-278, pls 6-8.

BEURLEN K. 1930. - Nachträge zur Decapodenfauna des Schwäbischen Jura. Neues Jahrbuch für Mineralogie, Geologie und Paläontologie. Beilage-Band 64: 219-234.

BEURLEN K. 1944. - Neue Reste von Proeryon (Crustacea, Decapoda, Eryonidea). Neues Jahrbuch für Mineralogie, Geologie und Paläontologie, Abhandlungen, Abteilung B: Geologie, Paläontologie 88: 374-384.

Beurlen K. \& Glaessner M. F. 1930. - Systematik der Crustacea Decapoda auf stammesgeschichtlicher Grundlage. Zoologische Jahrbücher. Abteilung Systematik, Ökologie und Geographie der Tiere 60: 49-84.

Bravi S., Garassino A., Bartiromo A., Audo D., Charbonnier S., Schweigert G., Thévenard F. \& LONGOBARDi C. 2014. - Monte Fallano Plattenkalke (Middle Jurassic: Bajocian-Bathonian) (Campania, southern Italy): first report on terrestrial plants, fishes, and decapod crustaceans. Neues Jahrbuch für Geologie und Paläontologie Abhandlungen 272 (1): 79-107.

BRODERIP W. J. 1835. - Description of some Fossil Crustacea and Radiata. Proceedings of the Geological Society of London 2: 201-202.

BronN H. G. 1858. - Beiträge zur triasischen Fauna und Flora der bituminösen Schiefer von Raibl. Neues Jahrbuch für Mineralogie, Geognosie, Geologie und Petrefakten-Kunde 1858: 1-32.

BurKenROAD M. D. 1963. - The evolution of the Eucarida, (Crustacea, Eumalacostraca), in relation to the fossil record. Tulane Studies in Geology 2 (1): 2-17.
CARTER J. 1886. - On the decapod crustaceans of the Oxford Clay. Quarterly Journal of the Geological Society 42: 542-559.

Cartes J. E. \& Sardà F. 1992. - Abundance and diversity of decapod crustaceans in the deep-Catalan Sea (Western Mediterranean). Journal of Natural History 26: 1305-1323.

Charbonnier S. 2009. — Le Lagerstätte de La Voulte: un environnement bathyal au Jurassique. Mémoires du Muséum national d'Histoire naturelle 199: 272 p.

ChARBOnNIER S. 2010. - Les gisements à conservation exceptionnelle dans les collections: l'exemple de La Voulte et de Montceau-les-Mines (France), in Saint Martin J.-P., Saint Martin S., Oaie G., SEghedi A. \& GRIGORESCU D. (eds), Le patrimoine paléontologique. Des trésors du fond des temps. GeoEcoMar, Bucarest: 95-112.

Charbonnier S., Vannier J., Gaillard C., Bourseau J.-P. \& Hantzpergue P. 2007a. — The La Voulte Lagerstätte (Callovian): evidence for a deep water setting from sponge and crinoid communities. Palaeogeography, Palaeoclimatology, Palaeoecology 250 (1): 216236. http://dx.doi.org/10.1016/j.palaeo.2007.03.013

Charbonnier S., Vannier J. \& Riou B. 2007b. - New sea spiders from the Jurassic La Voulte-sur-Rhône Lagerstätte. Proceedings of the Royal Society B: Biological Sciences 274 (1625): 2555-2561. http://dx.doi. org/10.1098/rspb.2007.0848

Charbonnier S., Vannier J., Hantzpergue P. \& GaIllard C. 2010. - Ecological significance of the arthropod fauna from the Jurassic (Callovian) La Voulte Lagerstätte. Acta Palaeontologica Polonica 55 (1): 111-132.

Charbonnier S., Garassino A., Pacaud J.-M. \& SCHWeigert G. 2012. - Rediscovery of the type material of Eryon cuvieri Desmarest, 1817 (Crustacea, Decapoda, Eryonidae) and nomenclatural consequences. Geodiversitas 34 (4): 849-855. http:// dx.doi.org/10.5252/g2012n4a7

Charbonnier S., Garassino A., Schweigert G. \& SIMPSON M. 2013. - A worldwide review of fossil and extant glypheid and litograstrid lobsters (Crustacea, Decapoda, Glypheoidea). Mémoires du Muséum national d'Histoire naturelle 205, 304 p.

Desmarest A.-G. 1817. — Crustacés fossiles, in Société de Naturalistes et d'Agriculteurs (eds), Nonveau Dictionnaire d'Histoire naturelle, appliquée aux Arts, à l'Agriculture, à l'Économie rurale et domestique, à la Médecine, etc. 7. Déterville, Paris: 495-519.

Desmarest A.-G. 1822. — Les crustacés proprement dits, in Brongniart A. \& Desmarest A.-G. (eds), Histoire naturelle des crustacés fossiles sous les rapports zoologiques et géologiques. F.-G. Levrault, Paris: 67-142.

Dietl G. \& SChweigert G. 2001. - Im Reich der Meerengel-Fossilien aus dem Nusplinger Plattenkalk. F. Pfeil, Munich, 114 p. 
DieTl G. \& SCHWEIGERT G. 2004. — The Nusplingen lithographic limestone - a "Fossil Lagerstaette" of late Kimmeridgian age from the Swabian Alb (Germany). Rivista Italiana di Paleontologia e Stratigrafia 110: 303-309.

Dietl G. \& Schweigert G. 2011. - Im Reich der Meerengel - Fossilien aus dem Nusplinger Plattenkalk (2nd edition). F. Pfeil, Munich, 144 p.

ELMI S. 1967. — Le Lias supérieur et le Jurassique moyen de l'Ardèche. Documents des Laboratoires de Géologie de la Faculté des Sciences de Lyon 19 (2): 257-507.

ELMI S. 1990. - Stages in the evolution of late Triassic and Jurassic carbonate platforms: the western margin of the Subalpine Basin (Ardèche, France), in Tucker M. E., Wilson J. L., Crevello P. D., SARG J. R. \& Read J. F. (eds), Carbonate Platforms, Facies, Sequences and Evolution, 9. Blackwell Scientific Publications, Oxford, London, Edinburgh, Boston, Melbourne: 109-144.

ÉTALLON A. 1859. - Description des crustacés fossiles de la Haute-Saône et du Haut-Jura. Bulletin de la Société géologique de France 16: 169-205.

Eudes-DeslongChamps E. 1868. - Note sur des céphalopodes et des crustacés renfermés dans la cavité abdominale de poissons et de reptiles des argiles infraoolithiques. Bulletin de la Société linnéenne de Normandie, 2eme série, 1: 156-169.

Feldmann R. M., SChweitzer C. E. \& Haggart J. W. 2013. - A new genus and species of polychelid lobster (Crustacea, Decapoda, Eryonidae) from the Early Jurassic (Hettangian) of British Columbia. Canadian Journal of Earth Sciences 50 (2): 135-141.

FirTh R. M. \& PeQUegnat W. E. 1971. - Deep-Sea Lobsters of the Families Polychelidae and Nephropidae (Crustacea, Decapoda) in the Gulf of Mexico and Caribbean Sea. Texas A\&M University, Department of Oceanography, $106 \mathrm{p}$.

FisCHER J.-C. 2003. - Invertébrés remarquables du Callovien inférieur de la Voulte-sur-Rhône (Ardèche, France). Annales de Paléontologie 89: 223-252.

FRAAS O. 1855. - Beiträge zum obersten weissen Jura in Schwaben. Jahrshefte des Vereins für vaterländische Naturkunde in Württemberg 11: 77-107.

FrICKHINGER K. A. 1994. - Die fossilien von Solnhofen, Goldschneck-Verlag, Korb, 336 p.

FriCKHINGER K. A. 1999. - Die fossilien von Solnhofen. Vol. 2. Goldschneck-Verlag, Korb, 190 p.

GaLIL B. S. 2000. - Crustacea Decapoda: review of the genera and species of the family Polychelidae WoodMason, 1874, in Crosnier A. (ed.), Résultats des campagnes MUSORSTOM, Volume 21. Mémoires du Muséum national d'Histoire naturelle 184: 285-387.

Garassino A. \& TeruZZI G. 1993. - A new decapod crustacean assemblage from the Upper Triassic of Lombardy (N. Italy). Paleontologie Lombarda Nuova serie 1, 27 p., 5 pls.
Garassino A. \& Schweigert G. 2004. - Cycleryon wulfi n. sp. (Crustacea: Decapoda: Eryonidae) from the Upper Jurassic of Eichstätt (Bavaria, S Germany). Atti della Società italiana di Scienze naturali e del Museo civico di Storia naturale in Milano 145 (2): 243-250.

Garassino A. \& SchWEIgert G. 2006. - The Upper Jurassic Sonhofen decapod crustacean fauna: review of the types from old descriptions. Part I. Infraorders Astacidea, Thalassinidea, and Palinura. Memorie della Società Italiana di Scienze Naturali e del Museo Civico di Storia Naturale di Milano 34 (1): 1-64.

Garassino A., Teruzzi G. \& Dalla Vecchia F. M. 1996. - The macruran decapod crustaceans of the Dolomia di Forni (Norian, Upper Triassic) of Carnia (Udine, NE Italy). Atti della Società italiana di Scienze naturali e del Museo civico di Storia naturale in Milano 136 (1): 15-60.

Glaessner M. F. 1929. - Crustacea Decapoda, in POMPeCKJ F. J. (ed.), Fossilium Catalogus I: Animalia, Pars 41. W. Junk, Berlin: 1-464.

GLAESSNER M. F. 1965. - Vorkommen fossiler Dekapoden (Crustacea) in Fisch-Schiefern. Senckenbergiana Lethaea 46a: 111-122.

GlaEssner M. F. 1969. — Decapoda, in Moore R. C. \& TEICHERT C. (eds), Treatise on Invertebrate Paleontology, Part R. Arthropoda 4 (2). Geological Society of America, Boulder, Colorado and University of Kansas Press, Lawrence, Kansas: R400-R533.

Gore R. H. 1984. - Abyssal lobsters, genus Willemoesia (Palinura, Polychelidae), from the Venezuela Basin, Caribbean Sea. Proceedings of the Academy of Natural Sciences of Phyladelphia 135: 1-11.

Grote A. R. 1873. - "Deidamia”. Nature 8: 485.

HaAN W., DE 1833-1850. - Crustacea, in Siebold PH. F. VON (ed.), Fauna Japonica sive descriptio animalium, quae in itinere per Japoniam, jusse et auspiciis superiorurn, qui summum in India Batavia Imperium tenent, suscepto, annis 1823-1830 collegit, notis observationibus et adumbrationibus illustravit. A. Arnz, Lugdunum Batavorum: 1-243.

Hauff B. \& Hauff R. B. 1981. - Das Holzmadenbuch, Hauff-Stiftung, Holzmaden, $136 \mathrm{p}$.

Hebenstreit J. E. 1743. - Museum Richterianum, Fritsch C., Liepzig, 384 p.

Heller C. 1862. - Beiträge zur näheren Kenntniss der Macrouren. Sitzungsberichte der Akademie der Wissenschaften in Wien, mathematisch-physikalische Klasse 45 (1): 389-426.

HolTHuis L. B. 1974. - The lobsters of the superfamilly Nephropidea of the Atlantic ocean (Crustacea: Decapoda). Bulletin of Marine Science 24 (4) : 723-884.

ICZN 1999. - International Code of Zoological Nomenclature. International Trust for Zoological Nomenclature. The Natural Museum, London, v-xxix, 1-306.

KnebeL W. vON. 1907. — Die Eryoniden des oberen Weissen Jura von Süddeutschland. Archiv für Biontologie 2: 195-233. 
KNORR G. W. 1755. — Sammlung von Merckwürdigkeiten der Natur und Alterthümern des Erdbodens, welch petrificirte Cörper enthält aufgewiesen und beschrieben. A. Bieling, Nürnberg: 1-30 pls.

Kunn O. 1952. - Neue Crustacea Decapoda und Insecta aus dem untersten Lias $\varepsilon$ von Nordfranken. Palaeontographica Abteilung A, 101 (5-6): 153-166.

LAGARDÈre J.-P. 1973. - Distribution des Décapodes dans le sud du Golfe de Gascogne. Revue des Travaux de l'Institut des Pêches Maritimes 37 (1): 77-95.

LAMARCK J.-.B. DE 1838. - Histoire naturelle des animaux sans vertèbres, 5. P. Renouard, Paris, 699 p.

LATREILLE P. A. 1802. - Histoire naturelle, générale et particulière, des Crustacés et des Insectes, 3. F. Dufart, Paris, $468 \mathrm{p}$.

LeVITSKI, E. C. 1974. - Fossil decapod crustaceans from the vicinity of the Bakhchisarai (the Crimea). Byulletin Moskovskogo Obshchestva Ispytatelei Prirody Otdel Geologicheskii 49 (6): 101-119.

Martin J. W. 2014. — Polychelida, in Martin J. W, Olesen J, HøEg J. T. (eds), Atlas of Crustacean Larvae. Johns Hopkins University Press, Baltimore: 279-282.

MeYer H. vON 1836. - Beiträge zu Eryon, einem Geschlechte fossiler langschwänänziger Krebse. Nova Acta Physico-Medica Academiae Caesareae LeopoldinoCarolinae Naturae Curiosorum 18 (1): 263-283.

MÜNSTER G. GRAF ZU 1839. - Decapoda Macroura. Abbildung und Beschreibung der fossilen langschwänzigen Krebse in den Kalkschiefern von Bayern. Beiträge zur Petrefakten-kunde 2: 1-88.

OpPel A. 1862. - Ueber jurassische Crustaceen (Decapoda macrura). Palaeontologische Mittheilungen aus dem Museum des koeniglich Bayerischen Staates 1: 1-120.

PICTET F. J. 1846. - Traité élémentaire de paléontologie, Vol. 4. J.-G. Fick, Genève, 458 p.

PINNA G. 1968. - Gli Erionidei della nuova fauna sinemuriana a crostacei decapodi di Osteno in Lombardia. Atti della Società italiana di Scienze naturali e del Museo civico di Storia naturale in Milano 107 (2): 93-134.

PINNA G. 1969. - Due nuovi esemplari di Coleia viallii Pinna, del Sinemuriano inferiore di Osteno in Lombardia. Annali del Museo Civico di Storia Naturale di Genova 77: 626-632.

ROMAN F. 1928. - 1. Horizon à nodules de crustacés et poissons, in SAYN G. \& ROMAN F. (eds), Monographie stratigraphique et palaéontologique du Jurassique moyen de la Voulte-sur-Rhône. Travaux du laboratoire de géologie de la faculté des sciences de Lyon 11 (13): 1-165, pls 1-12.

Schindelin J., Arganda-Carreras I., Frise E., KaYNig V., Longair M., Pietzsch T., Preibisch S., Rueden C., SaAlfeld S., Schmid B., Tivenez J.-Y., White D. J., Hartenstein V., Eliceiri K., TOMANCAK P. \& CARDONA A. 2012. - Fiji: An Open-Source Platform for Biological-Image Analysis. Nature Methods 9 (7): 676-682. http://dx.doi.org/10.1038/nmeth.2019
SChlotheim E. F. vON 1820. - Die Petrefactenkunde auf ibrem jetzigen Standpunkte durch die Beschreibung seiner Sammlung versteinerter und fossiler Überreste des Thier- und Pflanzenreichs der Vorwelt erläutert. Becker'schen Buchhandlung, Gotha, 100 p.

SCHLOTHeIM E. F. VON 1822. — Nachträge zur Petrefactenkunde. Becker'schen Buchhandlung, Gotha, $114 \mathrm{p}$.

Scholtz G. \& Richter S. 1995. - Phylogenetic systematics of the reptantian Decapoda (Crustacea, Malacostraca). Zoological Journal of the Linnean Society 113: 289-328.

SChWeIgerT G. 1997. — Bibliographie des Nusplinger Plattenkalks von 1823-1997. Profil 11: 341-349.

SCHWEIGERT G. 2001. - Dimorphismus bei Krebsen der Gattung Cycleryon (Decapoda, Eryonidae) aus dem Oberjura Süddeutschlands. Stuttgarter Beiträge zur Naturkunde, Serie B, 305: 1-21.

SCHWEIGerT G. \& DietL G. 1999. — Neubeschreibung von 'Eryon longipes O. Fraas' (Crustacea, Decapoda, Eryonidea) aus dem Nusplinger Plattenkalk (OberKimmeridgium, Schwäbische Alb). Stuttgarter Beiträge zur Naturkunde, Serie B, 274: 1-19.

Schweigert S. \& Herd K. J. 2010. — Ein Vielscherer aus der Unterkreide. Fossilien 27 (4): 212-217.

Schweigert G., Dietl G., Kapitzke M., Rieter M., Ilg A. \& Russ B. 2012. - Der Nusplinger Plattenkalk (Weißer Jura ל) - Grabungskampagne 2011. — Jahreshefte der Gesellschaft für Naturkunde in Württemberg, 168: 53-73.

Schweitzer C. E., \& Feldmann R. M. 2001. — New Cretaceous and Tertiary decapod crustaceans from western North America. Bulletin of the Mizunami Fossil Museum 28: 173-210.

Schweitzer C. E., Feldmann R. M., Garassino A., KARASAWA H. \& SCHWEIGERT G. 2010. — Systematic list of fossil decapod crustacean species. Crustaceana Monographs 10: 1-222.

SeCRÉTAN S. 1985. - Conchyliocarida, a class of fossil crustaceans: relationships to Malacostraca and postulated behaviour. Transactions of the Royal Society of Edinburgh, 76: 381-389.

SPENCE BATE C. 1878. - On the Willemoesia Group of Crustacea. The annals and magazine of natural history, including Zoology, Botany, and Geology Fifth series 2 (10): 273, $1 \mathrm{pl}$.

Spence Bate C. 1888. - Report on the Crustacea Macrura collected by H.M.S. Challenger during the years 1873-1876, in Wyville ThOMSON C. \& MuRRAY J. (eds), Report on the Scientific Results of the Voyage of the H.M.S. Challenger during the Years 1873-76 under the Command of Captain Georges S. Nares R.N., F.R.S. and the Late Captain Frank Tourle Thomson, R.N., Zoology, 24. Neill, Edinburgh: 1-942.

StebiInG T. R. R. 1888. - Report on Amphipoda collected by H.M.S. Challenger during the Years 1873- 
1876, in Wyville Thomson C. \& Murray J. (eds), Report of the Scientific Results of the Voyage of H.M.S. Challenger during the Years 1873-76 under the Command of Captain George S. Nares, R.N. F.R.S. and the Late Captain Frank Tourle Thomson, R.N., Zoology, 29. Neill, Edinburgh: 1-1737.

Teruzzi G. 1990. — The genus Coleia Broderip, 1835 (Crustacea, Decapoda) in the Sinemurian of Osteno in Lombardy. Atti della Società italiana di Scienze naturali e del Museo civico di Storia naturale in Milano 131 (4): 85-104.

Vannier J., Chen J.-Y., Huang D.-Y., CharbonniER S. \& WANG X.-Q. 2006. - The Early Cambrian origin of thylacocephalan arthropods. Acta Palaeontologica Polonica 51 (2): 201-214.

VAN STRAelen V. 1923. — Les crustacés décapodes du Callovien de la Voulte-sur-Rhône (Ardèche). Comptes Rendus hebdomadaires des Séances de l'Académie des Sciences 175: 982, 983.

VAN STRaelen V. 1925. - Contribution à l'étude des crustacés décapodes de la période jurassique. Mémoires de la Classe des Sciences de l'Académie royale de Belgique 7: 1-462.

Villier L., Charbonnier S. \& Riou B. 2009. - Sea Stars from Middle Jurassic Lagerstätte of La Voultesur-Rhône (Ardèche, France). Journal of Paleontology, 83 (3): 389-398. http://dx.doi.org/10.1666/08-030.1
Wilby P. R. 2002. — La Voulte-sur-Rhône: exquisite cephalopod preservation, in BOTTJER D. J., ETTER W., HAGADORN J. W. \& TANG C. M. (eds), Exceptional Fossil Preservation. Columbia University Press, New York, $403 \mathrm{p}$.

Wilby P. R., Briggs D. E. \& Riou B. 1996. - Mineralization of soft bodied invertabrates in a Jurassic metalliferous deposit. Geology 24 (9): 847-850.

Willemoes-SuHM R. vON, 1875. - On some Atlantic Crustacea from the 'Challenger' Expedition. The Transactions of the Linnean Society of London. Zoology. Second Series 1: 23-59, pls 6-13.

WoOd-Mason J. 1874. - On Blind Crustaceans. Proceedings of the Asiatic Society of Bengal 1874: 180, 181.

Woods H. 1925-1931. - A Monograph of the Fossil Macrurous Crustacean of England. The Palæontographical Society, London: 1-122, pls 1-27.

WOODWARD H. 1866. - Notes on the species of the genus Eryon Desmarest from the Lias and Oolite of England and Bavaria. Quarterly Journal of the Geological Society of London 22: 494-502.

WOODWARD H. 1881. - Contribution to the study of fossil Crustacea. The Geological Magazine, new series Decade II, 8: 529-534.

WOODWARD H. 1911. - On a new species of Eryon from the Upper Lias, Dumbleton Hill. The Geological Magazine, new series Decade V, 8: 307-311.

Submitted on 24 February 2014; accepted on 5 May 2014; published on 26 December 2014. 